\title{
1962 Küba Krizi: Amerikan Arşivleri Üzerinden Bir Okuma*
}

\author{
The 1962 Cuban Crisis: A Reading from the American Archives
}

\author{
Kaan Kutlu ATAÇ ${ }^{\star \star}$ - Begüm Sezin ÖZCAN ${ }^{\star \star \star}$
}

$\ddot{0} z$

Bu çalşsmanin amacı Soğuk Savaşın en önemli nükleer krizlerinden birisi olan 1962 Küba Krizinin Amerikan arşiv belgeleri üzerinden bir okumasinn yaplmasıdrr. Arşiv belgeleri özellikle kriz süresince Amerikan karar alma mekanizmasmmn en tepesinde yer alan Başkan Kennedy'nin milli güvenlikle ilgili kurumlarn koordineli çalşmasinm sağlanmasındaki etkisini ortaya koyması bakımindan önemlidir. Nitekim bu çerçevede Kennedy'nin kriz süresince günde birkaç defa toplanan ve milli güvenlikle ilgili kurumlarn temsilcilerinin görüslerini serbestçe ifade ettikleri bir platform olarak Milli Güvenlik Konseyi İcra Kurulu (The Executive Committee of the National Security Councill ExComm) ön plana çlkmaktadir. ExComm toplantilarna ait tutanaklar ve diğer arşiv belgeleri kriz sürecinin yönetilmesindeki mekanik yapinn anlaşlmasinda önemli bir nokta olarak karşımıza çıkmaktadrr. Bu anlamda çalı̧ma, nükleer savaşın eşï̆indeki Amerika'nn milli güvenliğe bağl olarak dis politika karar alma sürecinde liderlik yapısinn yeri nedir ve liderlik yapıs hangi saikler üzerinden hareket etmiştir sorusuna cevap vermektedir. Bu çerçevede çalısmanin ilk bölümünde kuramsal değerlendirme yer almaktadrr. İkinci bölümde krize giden yolda hangi parametrelerin etkisi olduğu ele alnmıştrr. Üçüncü bölümde Küba Krizi'nin gelisimi detayl olarak kronolojik safhalaryla ele alnnrken Amerikan karar ahclarn krizin gelişimine dair düşünceleri arşiv belgeleri üzerinden incelenmisstir. $B u$ noktada ABD Dissişleri Bakanliğ'nn Foreign Relations of the United States (FRUS) belgeleri ve gizlilik dereceleri kaldirlmıs CIA belgeleriyle desteklenerek detaylandimlmıstrr. Son bölümde krizin sona ermesiyle ortaya çıkan uluslararası ortam açılanmışstr.

\footnotetext{
${ }^{\star}$ Bu çalışma yüksek lisans tezinin bir bölümünün genişletilmiş halidir.

* Dr. Öğr. Üyesi, Mersin Üniversitesi, İktisadi ve İdari Bilimler Fakültesi, Uluslararası İlişkiler Bölümü, Mersin, Türkiye, ORCID: 0000-0003-3435-9073, e-posta: kaanatac@mersin.edu.tr.

${ }^{\star \star \star}$ Mersin Üniversitesi Uluslararası İlişkiler Uzmanı, Mersin, Türkiye, ORCID 00000001-8245-0459, e-posta: begumsezin@gmail.com.
}

Geliş Tarihi / Submitted: 29.01.2021

Kabul Tarihi / Accepted: 02.07.2021 
Anahtar Kelimeler: Amerika Birleşik Devletleri, Soğuk Savaş, Başkan Kennedy, Küba, Kriz.

\section{Abstract}

The aim of this study is to explore the 1962 Cuban Crisis, one of the most important nuclear crises of the Cold War, through the American archival documents. Archival documents are especially important in that they reveal the influence of President Kennedy, who was at the top of the American decision-making mechanism during the crisis, in ensuring the coordinated work of institutions related to national security. As a matter of fact, in this context, the Executive Board of the National Security Council (The Executive Committee of the National Security Council/ ExComm) stands out as a platform where Kennedy convened several times a day during the crisis and where representatives of institutions related to national security express their views freely. Archive documents of ExComm meetings appear to be an important point in understanding the mechanical nature of the crisis process. In this sense, the study answers the question of what is the place of the leadership structure in the foreign policy decision-making process, depending on the national security of America on the verge of nuclear war, and what motives the leadership structure acted on. In this context, theoretical information will be included in the first stage of the study. In the second part, it is discussed what parameters have an impact on the road to the crisis. In the third chapter, while the development of the Cuban Crisis is discussed in detail in chronological stages, the thoughts of the American decision makers on the development of the crisis are examined through archive documents. At this point, the Foreign Relations of the United States (FRUS) documents of the US Department of State are supported and detailed with CIA documents whose secrecy degrees have been lifted. In the last section, the international environment that emerged with the end of the crisis was explained.

Keywords: The United States of America, the Cold War, President Kennedy, the Cuba Crisis.

\section{Giriș}

$\mathrm{Bu}$ çalışma Amerika Birleşik Devletleri (ABD) ve Sovyet Sosyalist Cumhuriyetler Birliği (SSCB) arasında yaşanan 1962 Küba Krizi’ne Amerikan perspektifinden milli güvenlikle ilgili kurumların siyasi karar alıcı ile nasıl koordineli çalıştı̆̆ 1 ve liderlik yapısının krizde hangi saiklerle hareket ettiği sorusuna cevap niteliğindedir. $\mathrm{Bu}$ çerçevede Başkan Kennedy'nin kriz süresince günde birkaç defa topladığı ve milli güvenlikle ilgili kurumların temsilcilerinin görüşlerini serbestçe ifade ettikleri bir platform olarak Milli Güvenlik Konseyi İcra Kurulu (The Executive Committee of the National Security Council/ExComm) ön plana çımaktadır. 
ExComm toplantılarına ait arşiv belgeleri kriz sürecinin mekanik yapısının anlaşılmasında önemli bir nokta olarak karşımıza çıkmaktadır. Bu anlamda çalışma, nükleer savaşın eşiğindeki Amerika'nın milli güvenliğe bağlı olarak dış politika karar alma sürecinde liderlik yapısının yeri nedir ve liderlik yapısı hangi saikler üzerinden hareket etmiştir sorusuna cevap vermektedir. ABD'nin 35. Başkanı John Fitzgerald Kennedy döneminde patlak veren Küba Krizi'nin salt ABD ve SSCB odaklı ortaya çıkmadığı iddia edilebilir. 1962 Küba Krizi’nin altyapısında tetikleyici süreç 4 Ekim 1957'de SSCB'nin Sputnik yapay uydusunu uzaya firlatmasıdır. Bu gelişme sonrası ABD'de 7 Kasım 1957'de Horace Rowan Gaither başkanlığında toplanan komitenin "Nükleer Çağda Caydırıcılık ve Hayatta Kalma" (Deterrence $\mathcal{E}$ Survival in the Nuclear Age) başlıklı raporu Milli Güvenlik Konseyi'ne sunması, Türkiye'de nükleer silahların konuşlandırılması kararına neden olmuştu. ${ }^{1}$ Buna istinaden de Fidel Castro Küba'sının 19. yüzyıldan 20. yüzyıl ortalarına kadar ABD'yle ilişkisinde sarsıntılar yaşaması Castro'nun SSCB'yle yakınlaşmasını ve bilahare Küba'ya Sovyet nükleer füzelerinin yerleştirilmesi sürecini tetiklemiştir.

\section{Küba Krizinin Arka Planı}

Başkan Kennedy, önceki başkan Dwight David Eisenhower döneminde Türkiye'ye konuşlandırılan Jüpiter füzelerinin kaldırılması için 29 Mart 1961 MGK toplantısında CIA ve Savunma Bakanlığı temsilcilerinin oluşturduğu komiteden füzelerin durumunun değerlendirilerek kendisine bir tavsiyede bulunulmasını istedi. ${ }^{2} 22$ Haziran'da Dışişleri Bakanlığı'ndan George C. McGhee, Kennedy'nin Milli Güvenlik Danışmanı McGeorge Bundy'e Kruşçev'in Berlin sorunundan dolayı Viyana'da gösterdiği sert tutumunun ardından Jüpiterlerin kaldırılmamasını önerdi. ${ }^{3}$ Ayrıca daha önce Türkiye'ye CENTO'da (Merkezi Antlaşma Teşkilatı) bu konunun

\footnotetext{
${ }^{1}$ CIA, "Report to the President by the Security Resources Panel of the ODM Science Advisory Committe, Deterrence ESurvival in the Nuclear Age", 7 November 1957, p. 1-6 ve https:/www.cia.gov/readingroom/docs/CIA-RDP86B00269R000300020003-3.pdf (Erişim tarihi: 13.03.2021).

${ }^{2}$ Foreign Relations of the United States (FRUS), Eastern Europe; Cyprus; Greece; Turkey, Volume XVI, 1961-1963, p. 695.

31961 Berlin Krizi ile ilgili özellikle bkz. Frederick Kempe, Berlin 1961: Kennedy, Khrushchev, and the Most Dangerous Place on Earth, G.P. Putnam's Sons, New York, 2011.
} 
dile getirilmesiyle Türkiye'nin füzeleri prestij kaynağı görmesinden dolayı bu teklife olumlu yaklaşmadığını ekledi. ${ }^{4}$

1962 başlarında Washington'ın Küba'ya bir istila planı hazırlamasından tedirgin olan Sovyet hükümeti, 12 Nisan'da Küba'ya 180 SA-2 füzesinin teslim edilmesini onaylayarak herhangi bir istilaya karşı ihtiyatlı önlemler alınmasını da onayladı. ${ }^{5} 21$ Mayıs'ta Savunma Konseyi'ne sunulan ve 24 Mayıs'ta onaylanan bu plan sonrası Kruşçev, Mayıs ve Haziran'da Küba'ya 1.050 mil gidebilen yirmi dört orta menzilli R-12 füzesi ve 2.100 mil menzile sahip olan ara menzilli R-14 füzesi konuşlandırma kararı aldı. Raul Castro başkanlığındaki Küba heyetinin Temmuz'da Moskova'ya gelmesi sonucuyla Küba'ya konuşlandırılacak füzelerin ve silah sevkiyatlarının görüşmesi yapıldı. Görüşmelerin neticesinde anlaşma hazırlanarak temmuz sonunda ilk sevkiyatın yapılması kararlaştırıldı. ${ }^{6}$

Ağustos sonlarına doğru Amerikan istihbaratı Raul Castro'nun Moskova'ya geldiğinin haberini aldı. ${ }^{7}$ CIA'nin, SSCB'nin Küba'ya nükleer füze gönderilip gönderilmeyeceği yönündeki ilk değerlendirmeleri olumsuzdu. Ancak bu değerlendirme yanlış çıtı. 29 Ağustos'ta Moskova'nın gönderdiği füzelerin yapım aşamasında olduğu tespit edildi. ${ }^{8}$ Buna rağmen 3 Eylül'de Dışişleri Bakanlığı'ndan Walt Rostow, Kennedy'e Küba'da konuşlandırılan Sovyet teçhizatının ABD'nin güvenliğine herhangi tehdit oluşturmadığını, bunların ABD'nin tedirgin olması için yapılan psikolojik bir hareket olduğunu ifade etti. ${ }^{9}$ Ertesi gün Beyaz Saray, Kennedy'nin Küba'daki teçhizatlar ile ilgili açıklamasını yayınladı. Açıklamada asıl tehlikenin Küba'da konuşlandırılan füzelerin değil Sovyetlerin saldırganlığı olduğu ifade edildi. ${ }^{10}$ Amerikan siyasi karar mekanizması kendisine sunulan istihbarat raporlarının ve diplomatik değerlendirmelerin gölgesinde

\footnotetext{
${ }^{4}$ FRUS, Eastern Europe; Cyprus, Greece, Turkey, p. 703-704.

5 Lawrence Freedman, Kennedy's Wars: Berlin, Cuba, Laos And Vietnam, Oxford University Press, New York, 2000, p. 162.

${ }^{6}$ Allyn Bruce, Blight James G. vd., "Essence of revision: Moscow, Havana and the Cuban Missile Crisis”, International Security, 1989/1990, 14(3), 136-172, p. 149.

${ }^{7}$ FRUS, Cuba: January 1961-September 1962, Volume X, 1961-1963, p. 950.

${ }^{8}$ A.g.e., p. 968.

${ }^{9}$ A.g.e., p. 1025.

${ }^{10}$ Robert Dallek, An Unfinished Life: Fohn F. Kennedy, 1917-1963, Little, Brown and Company, New York, 2003, p. 539.
} 
kalmıştı. Amerika Birleşik Devletleri'nde Sovyetler Birliği Büyükelçisi Anatoly Dobrynin, Küba'da saldırı amaçlı değil savunma amaçlı silahların var olduğunu ABD'nin BM Büyükelçisi Adlai Stevenson'a açıklasa da CIA direktörü John McCone, sürekli olarak keşif ve gözetleme operasyonlarının yapılması önerisinde bulundu. ${ }^{11}$

19 Eylül'de Küba'daki askerî yığınakla ilgili olarak "Özel Milli İstihbarat Değerlendirmesi” (Special National Intelligence Estimate) yayınland. Değerlendirmede Sovyetlerin amacının ABD'nin Küba'ya karşı olası saldırısını önlemek ve Castro rejiminin savunmasını geliştirerek ABD'nin herhangi bir girişimini caydırmak amaçlı olduğu belirtildi. Ayrıca adanın batı bölgesine 12 SA-2 SAM alanının kurulduğu ve doğu bölgesinde de benzer konuşlandırmanın muhtemel olduğu öngörüldü. ${ }^{12} \mathrm{Bu}$ gelişmeler sonrası Senato tarafından ABD'nin güvenliğini tehlikeye atan bir askerî saldırı durumunun önlenmesi için başkana yetki veren karar kabul edildi. ${ }^{13}$ 28 Eylül'de Deniz Kuvvetleri keşif uçakları, Küba'ya giden Sovyet gemisi Kasimov'ün konteynerlerinde, Sovyet yapımı IL-28 bombardıman uçağının bulunduğunu tespit etti. ${ }^{14} 1$ Ekim'de SAM alanlarının analiziyle ilgili görüşmede de istihbaratın 15 SA-2 SAM alanı tespit ettiği belirtildi. ${ }^{15}$

Temmuz'dan sonraki süreçte Sovyetlerin Küba'ya yaptığı sevkiyatlar önemli ölçüde artmıştı: 85 gemi dolusu çeşitli askerî malzeme ve personel adaya ulaşmıştı. Küba'ya bu dönemde 25 MIG-21av önleme uçağının intikalinin gerçekleştiği öngörülmüştü. Ayrıca askerî tesislerin inşasında çalışacaklar ve teknisyenler de dâhil yaklaşık 4.500 Sovyet askerî uzman adaya gelmişti. ${ }^{16} \mathrm{Bu}$ gelişmeler çerçevesinde Kennedy, 9 Ekim'de Hava Kuvvetleri'nden veya CIA'e bağlı pilotlar ada üzerinde U-2 uçuşunu onayladı. ${ }^{17}$

\footnotetext{
${ }^{11}$ FRUS, Cuba, p. 1052.

${ }^{12}$ CIA, "Special National Intelligence Estimate, The Military Building in Cuba", 19 September 1962, p. 1-9 ve 7 https://www.cia.gov/readingroom/docs/CIA-RDP80B01676R0018000500 003-7.pdf (Erişim tarihi: 14.03.2021).

${ }^{13}$ Dallek, a.g.e., p. 541.

${ }^{14}$ The National Security Archives, September 28, 1962: "Photograph of Soviet ship Kasimov with IL-28 fuselages in crates", https://nsarchive2.gwu.edu/nsa/cuba_mis_cri/13.jpg (Erişim tarihi: 31.03.2021)

${ }^{15}$ FRUS, Cuban Missile Crisis and Aftermath, Volume XI, 1961-1963, p. 1.

${ }^{16}$ A.g.e., p. 7-8.

${ }^{17}$ A.g.e., p. 17.
} 
14 Ekim sabahı Hava Kuvvetleri'ne bağlı bir pilot Küba'da U-2 ile keşif görevine başladı. Ada üzerinde altı dakika süren ve 928 fotoğraf elde edilen uçuşta Küba'da Sovyetlere ait füze sahalarının varlığı kesinleşmişti. ${ }^{18}$ Pinar del Rio eyaletinde San Cristobal yakınlarında üç adet MRBM füze sahasının geliştirildiğini ortaya konuldu. Fotoğraf analistleri ayrıca Guanajay'de 2 adet IRBM alanı ve San Julian alanında Sovyet IL-28 bombardıman uçağ 1 için 21 kasa ortaya çıkard $1 .{ }^{19}$ Ertesi sabah 8.30 'da CIA Direktör Yardımcısı Carter, Bundy'e MRBM'lerin kesin kanıtlarını sunduğunda ABD'nin güneydoğu bölgesi ile Karayipler'de amfibi tatbikatı da başlatıldı. PHIBRIGLEX-62 kod adlı tatbikat 15-30 Ekim tarihleri arasında planlanmıstı. Tatbikatın amacı Porto Rico'daki Vieques Adasına bir amfibi saldırı yapmaktı. Simülasyonun amac1, "Ortsac" tiranını devirmekti. ${ }^{20}$ PHIBRIGLEX-62'ye yaklaş1k 20.000 deniz personeli ve 4.000 deniz piyadesi görev aldı. Tatbikat 20 Ekim'e kadar askıya alınmadı. ${ }^{21}$

Küba, artık en az 158 taktik ve stratejik nükleer silahla donatılmıştı. 1959'da Jüpiter füzelerinin Türkiye'ye konuşlandırılmasına tepki veren Kruşçev, Amerikalıların SSCB'yi askerî üslerle kuşatmanın ve tehdit etmenin nasıl bir şey olduğunu anlamalarını istiyordu. Ayrıca her ne kadar Castro, komünizme yönelmiş olsa da Kruşçev'in Castro'yu savunması önemli değildi. Castro, Küba'sının nükleer silahlarla donatılma kararında Kruşçev'in prestij ve itibarla ilgili düşünceleri büyük bir rol oynadı. Castro ise bu teklifi Küba rejimini ABD saldırısından korumak ve sosyalist bloğun stratejik konumunu desteklemek için tasarlanmış bir önlem olarak gördü. Ancak Castro, komünist dünya ve Kruşçev'in hedefleri için bir araç niteliğindeydi. ${ }^{22}$ Süreç her aktörün kendi çıkarları çerçevesinde diğerini optimal seviyede nasıl kullanacağına işaret etmesi bakımından önemliydi.

\footnotetext{
18 The National Security Archives, October 14, 1962: "U-2 phoghraph of a truck convoy approaching a deployment soviet MEBMs near Los Palacios at San Cristobal", https://nsarchive2.gwu.edu/nsa/cuba_mis_cri/14.jpg; October 14, 1962: U-2' photograph of MRBM site two nautical miles away from the Los Palacios deployment" https://nsarchive2.gwu.edu/nsa/cuba_mis_cri/15.jpg (Erişim tarihi: 31.03.2021)

${ }^{19}$ FRUS, Cuban Missile Crisis and Aftermath, p. 29.

${ }^{20}$ Küba işgalinin planlaması olan "Ortsac” Castro'nun adının tersten yazılışıydı.

${ }^{21}$ FRUS, Cuban Missile Crisis and Aftermath, p. 30.

${ }^{22}$ Michelle Getchell, The Cuban Missile Crisis And The Cold War: A Short History With Documents, Hackett Publising, Indianapolis, 2018.
} 


\section{Küba Krizi}

Kennedy krizin ilk günü olan 16 Ekim'e 08.45 'te Bundy tarafindan iletilen kötü haberle başladı. Başkan, hemen Kabine Odası'nda bir toplantı düzenlenmesini emretti. Burada alınacak ilk karar füzeleri ortadan kaldırmak ve nükleer bir savaş olasılığını ortadan kaldırmaktı. 1 saat 10 dakika süren tartışma için 11.50'de Kabine Odasında toplanıldı. ${ }^{23}$ Adalet Bakanı ve Başkan Kennedy'nin kardeşi olan Robert Kennedy, o günü SSCB'nin Küba'ya füze ve atom silahları yerleştirdiği Küba füze krizinin başlangıcı olarak hatırlayacakt1. ${ }^{24}$

Kabine üyeleri bir araya geldiğinde Kennedy ile beraber George Ball, Dışişleri Bakanı Dean Rusk ve Dışişleri Bakanlığından Alexis Johson; McNamara, Savunma Bakan Yardımcısı Roswell Gilpatric, Genelkurmay Başkanı General Maxwell D. Taylor ve CIA Direktörü Marshall Carter, Bundy, Hazine Bakanı C. Douglas Dillon, Başkan Yardımcısı Lyndon B. Johnson hazırdı. Hava fotoğrafçılığında uzman olan Arthur Lundahl ve Sidney Graybeal toplantıda bulunanlara U-2 fotoğrafları hakkında brifing verdi. ${ }^{25}$

SSCB'nin Florida sahillerinden yalnızca $145 \mathrm{~km}$ uzakta böyle bir teşebbüste bulunmaları ve Kremlin tarafından aldatılmaları ExComm üyelerinde şok etkisi yaratmıştı. ${ }^{26}$ Küba'daki teşebbüsle ilgili düşüncelerini dile getiren Rusk, alternatifli iki eylem planı üzerinde durdu. Buna göre eylemlerden ilki hızlı bir darbe yapılmasıydı. İkincisi ise Rio Paktı'nın ihlal edildiği gerekçesiyle Amerikan Devletleri Örgütü (Organization of American States $/ O A S$ ) prosedürünün harekete geçirilmesi hatta Havana'daki Kanada Büyükelçisi ya da BM Temsilcisi aracılığıyla Castro'ya haber verilmesiydi. Rusk, Kanada Büyükelçisi aracığıyla Castro’ya Küba'nın mağdur edildiğini, Sovyetlerin Küba'ya ihanet edeceğini ve Küba'yı yıkıma hazırlayacağının söylenmesi üzerinde durdu. Rusk' göre askerî eylemlerin de göz ardı edilmemesi gerektiğiydi. ${ }^{27}$ McNamara için de askerî seçenekler ön plandaydı. Birincisi, Küba'nın belirli bir kısmına hava saldırısında bulunmak; ikincisi,

${ }^{23}$ Dallek, a.g.e., p. 544-545.

${ }^{24}$ Robert Kennedy, Thirteen Days, Macmillan, London, 1968, p. 27.

${ }^{25}$ Dallek, a.g.e., p. 545-546.

${ }^{26}$ Sheldon Stern, The Week The World Stood Still: Inside The Secret Cuban Missile Crisis, Stanford University Press, California, 2005, p. 37.

${ }^{27}$ FRUS, Cuban Missile Crisis and Aftermath, p. 31-33. 
herhangi bir hava saldırısının yalnızca füze sahalarına değil gizlenmiş olan uçaklara ve bütün potansiyel nükleer depolama alanlarına yapılmasıydı. Taylor ise bir deniz ablukası önerisini dile getirdi. ${ }^{28}$ Castro'yu ortadan kaldırma ve Castro rejimini yıkma planına destek veren R. Kennedy ise, adanın işgal seçeneğini savundu. ${ }^{29}$

Komite, 18.30 'da tekrar toplandığında başkanın özel danışmanı Ted Sorensen ve Latin Amerika işlerinden sorumlu Edwin Martin de ekibe katıld1. ${ }^{30}$ Rusk, Castro'nun mevcut durumunun giderek tehlikeli olmaya başladığını bilmesi durumunda Moskova'yla yolları ayırabileceği, her halükârda Castro'ya ve Kruşçev'e doğrudan bir mesaj gönderme seçeneğinde 1srarcıyd1. ${ }^{31}$ Martin, mesajda füze sahaları hakkında ABD'nin bilgisinin olduğu, SSCB'nin Berlin konusunda imtiyaz elde etmek amacıyla füzeleri pazarlık konusuna dönüştüreceği hususunun yer alması gerektiği düşüncesindeydi. ${ }^{32}$ McNamara ise açı gözetim ilanı yapılmalıydı. Böylece gelecekte Küba'ya giren saldırı silahlarına karşı hemen süresiz abluka uygulanması Küba'nın herhangi bir saldırı hamlesine karşı SSCB'ye saldırmaya hazır olunacağı gösterilecekti. ${ }^{33}$ Taylor, stratejik pozisyonun önemli oranda değiştiğini vurgularken, R. Kennedy eylemsizliğin SSCB tarafından nükleer bir şantaj olarak kullanılacağı endişesini taşıyordu. Martin ise zayıflık işaretinin ortaya çıkmasının Sovyet saldırısını teşvik edeceğinden endişeliydi. ${ }^{34}$ Kennedy yönetimi ABD'nin elindeki opsiyonların nasıl değerlendirileceği konusunda siyasi anlamda fikir birliğinden uzak görünüyordu ve nitekim ortak bir karar alınamadan toplantı sona erdi.

Ertesi sabah Kennedy'nin danışmanları yeniden toplandığında hâkim olan endişe herhangi bir uyarı olmadan Küba'ya karşı yapılacak bir eylemde ABD'nin küresel düzeyde eleştirilere maruz kalacağıydı. Hem Kruşçev hem de Castro'nun uyarılmasına rağmen istenilen cevabın alınmaması durumunda bir eylem planı yapılması gerekiyordu. Bohlen ve Thompson,

\footnotetext{
${ }^{28}$ A.g.e., p. 33-35.

${ }^{29}$ Stern, a.g.e., p. 43.

${ }^{30}$ Dallek, a.g.e., p. 548.

${ }^{31}$ FRUS, Cuban Missile Crisis and Aftermath, p. 53.

${ }^{32}$ A.g.e., p. 53-54.

${ }^{33}$ A.g.e., p. 57.

${ }^{34}$ Stern, a.g.e., p. 48.
} 
Küba'daki Sovyet eylemlerinin Başkan Kennedy'i tuzağa düşürerek bir çatışma ortamının yaratılması endişesini taşıyordu. Acheson'ın süreç ile ilgili önerisi olayların gelişimine göre ve SSCB'nin tepkilerine göre tepki verilmesi yönündeydi. Kurul askerî harekâta alternatif olarak abluka ve savaş seçeneğini tartısssa da sabah toplantısında yine belirgin bir görüşün hâkimiyeti sağlanamadı. ${ }^{35}$ Amerikan topraklarına bir taş atımı mesafede nükleer bir kriz gelişirken Amerikan üst siyasi karar alma mekanizması bu krizde net bir hareket tarzı belirlemekte zorlanıyordu.

McCone, 09.30'da Kennedy'le bir araya geldiğinde başkan, MRBM'leri ve muhtemel hava sahalarını hedef alarak, uyarı yapılmaksızın derhal harekete geçilmesi konusunda meyilliydi. Brifing esnasında Kennedy, McCone'nin acilen Eisenhower'ı görmesini istedi. ${ }^{36}$ McCone, Eisenhower'a gelişmeleri aktardığında eski başkan şaşırtmamıştı. Soğuk Savaş'ın mimarlarından olan Eisenhower'a göre Kruşçev ve Castro ile ayrı ayrı ya da her ikisiyle birlikte yapılacak görüşmeler zaman kaybından başka bir şey değildi. ${ }^{37}$ Öte yandan aynı saatlerde Kuvvet Başkanları da MRBM sahalarına karşı gerçekleşecek bir saldırının geri dönülemez bir risk içerdiği hususunda hem fikirdiler. ${ }^{38}$ Genel olarak 17 Ekim'de, SSCB'nin Küba'ya taarruz silahları yerleştirmesinin amaçları konusunda ABD yönetiminin görüşü netleşmeye başlamıştı: Küba'ya karşı gerçekleşecek saldırı ihtimali durumunda kullanılmak üzere saldırgan veya misilleme güç sağlamak ve ABD’ye karşı saldırı yeteneği güçlendirmek. ${ }^{39}$ Tartışmada genellikle, Kruşçev ve Castro'ya yapılacak bir ikaz öncesinde askerî müdahalenin gerekli olup olmadığı; NATO, OAS ve diğerler örgütler de dâhil olmak üzere müttefiklere haber vermek ve istişarede bulunmak ve konunun Birleşmiş Milletler gündemine getirilmesi konularına odaklanıldı. ${ }^{40}$

${ }^{35}$ CIA, “Memorandum for the file”, 17 October 1962, p. 1-3 ve https://www.cia.gov/reading room/docs/CIA-RDP80B01676R001900100014-8.pdf (Erissim tarihi: 15.03.2021).

${ }^{36}$ CIA, "Brief Discussion with the President", 17 October 1962, p. 1 ve https://www.cia.gov/ readingroom/docs/CIA-RDP80B01676R001900100012-0.pdf (Erişim tarihi: 15.03.2021).

37 CIA, "Documents on the Cuban Missile Crisis", p. 167 ve https://www.cia.gov/ library/center-for-the-study-of-intelligence/csi-publications/books-and-monographs/

Cuban\%20Missile\%20Crisis1962.pdf (Erişim tarihi: 16.03.2021).

${ }^{38}$ FRUS, Cuban Missile Crisis and Aftermath, p. 100-101.

${ }^{39}$ A.g.e., p. 103.

${ }^{40}$ A.g.e., p. 104-105. 
Kennedy ve kurmayları 18 Ekim saat 11.00 'de tekrar toplandığında sabah saatlerinde CIA tarafından hazırlanan "Küba'daki Sovyet Misyon Tehdidinin Ortak Değerlendirilmesi" (Foint Evaluation of Soviet Missile Threat in Cuba) başlıklı rapor ellerindeydi. ${ }^{41}$ Rapora göre sekiz firlatıcı ve on altı SS-4 MRBM'den oluşan bir Sovyet alayının Batı Küba'da konuşlandırıldığı, bütün taarruz füze sistemlerinin SSCB kontrolünde olduğu ve saldırı eylemlerinin Sovyetler tarafından komuta ediliyordu. Ayrıca Küba'da, ikisi Banes ve Santa Cruz del Norte olmak üzere aktif üç kıyı savunma füzesi sahasının saptandığı ve Küba'da dokuzunun faaliyette olduğu düşünülen yirmi iki SA-2 bulunduğu, geriye kalanların da birkaç hafta içerisinde faaliyete geçebileceği bilgisi de vardı. İlaveten SS-4'ler için fırlatılma kararı alındığı takdirde on sekiz saat içerisinde ateşlenebileceğ $i$ de istihbarat raporunda yer aldı. Konuşlandırılan füzelerin gücü değerlendirildiğinde SSCB'nin Küba'yı bir güç gösterisi olarak kullanmasından daha çok bir stratejik üs olarak geliştirme amacında olduğu belirtildi. Son olarak Sovyetlerin, etkisi yüksek güdümlü füze sistemleriyle Küba'ya büyük bir askerî yatırımda bulunduğu ve bunu planlamasının en az bir yıl önce, planın hayata geçirilmesinin ise bahar aylarında olduğu tahmin ediliyordu. ${ }^{42}$ CIA'in sağladığı bilgiler sonucunda da karar alıcı ekipte hâkim olan görüş Küba'nın askerî olarak zorlayıcı bir tehdit olabileceği, eyleme geçilmediği takdirde SSCB'nin kendi arzularına göre hareket etmesinin ABD tarafından onaylandığı hissi yaratacağıydı. Ayrıca Küba'daki bu tahkimatın sökülüp atılması yalnızca hava gücü kullanılarak başarılamazdı ve kara unsurlarının da yer alacağı bir operasyon gerekliydi. Rusk'a göre, Sovyet tahkimatına cevap verilmediği takdirde ABD'nin taraf olduğu ittifaklar hızlı bir şekilde zarar görebilirdi. Rusk ayrıca Küba'ya karş1 yapılacak bir saldırının; Kore, Berlin veya ABD'ye karşı Sovyet misillemesine neden olabileceği düşünüyordu. ${ }^{43}$ Kennedy yönetiminde

\footnotetext{
${ }^{41}$ CIA'in değerlendirmeleri Sovyet Askerî İstihbarat Servisi GRU'dan devşirdiği Albay Oleg Penkovsky'nin verdiği bilgiler üzerinde temellendiriliyordu. Bu hassas haber kanalının korunması adına CIA özel bir sistem kurmuştu ve bu operasyona Ironbark adı verilmişti. Ayrica bkz. FRUS, Cuban Missile Crisis and Aftermath, p. 115.

${ }^{42}$ CIA, "Foint Evaluation of Soviet Missile Threat in Cuba", 18 October 1962, p. 1-6 ve https://www.cia.gov/readingroom/docs/CIA-RDP78T05449A000200030001-8.pdf

(Erişim Tarihi: 17.03.2021).

${ }^{43}$ Stern, a.g.e., p. 55.
} 
krizin bölgesel nitelikte kalmayacağ 1 küresel birçok sonucu olan sürece doğru evirildiği görüşü etkili olmaya başlamıştı.

Saat 17.00'yi gösterdiğinde Anderi Gromyko ve Dobrynin, Kennedy'le görüştü. Gromyko, Sovyetlerin sulh içinde bir arada yaşama siyasetinin arkasında durduğunu ve bir devletin başka bir devletin içişlerine müdahalesini desteklemediğini belirtti. SSCB yardımı sadece Küba'nın müdafaa yeteneklerini ve bu yeteneklerinin arttırılmasını amaçliyordu: "Ĕger taarruz amaçlı olsaydı SSCB böyle bir yardımda asla yer almazdl." "44 Aslında tam da bu anda Kennedy krizin çözümünü bu noktada bulmuş görünmektedir: Jüpiter Füzelerinin Türkiye'den çıkarılmas1. Ancak bu konuda kabinesinden yeterli desteğe henüz alamamıştı. Bundy, bu kararı desteklerken; Rusk, Küba-Türkiye alışverişinin çok kritik bir durum olduğu düşünüyordu. Bundy, Rusk'ın düşüncesine karşıydı ve iki ülke arasındaki takasın nükleer gerginliği en aza indirmenin tek yolu olduğunu savundu. Konu askerî değil politik bir meseliydi. McNamara'nın öngörüsü ise, Kruşçev'in ilerleyen günlerde ABD füzelerinin İtalya ve Türkiye'den sökülmesini isteyeceği yönündeydi. ${ }^{45}$ Başkan ve danışmanları arasında saatlerce süren tartışmalar sonucunda iki seçeneğe ağırlık kazandı: abluka ve istila. Rusk, Ball ve Johnson sınırlı bir hava saldırısından; McNamara ve Taylor kapsamlı bir hava saldırısından; Bohlen, Thompson ve Martin abluka seçeneğinden yanayd $1 .{ }^{46}$ Tartışmalar ışığında Küba'ya karşı girişilecek bir eylemde ek silahların Küba'ya gitmesinin önlenmesi için sınırlı bir abluka seçeneğine kararı verildi. Bu karar yasal gerekleriyle birlikte dünya kamuoyu ile paylaşılacaktı. Küba'ya karşı savaş ilanı ise yalnızca gerekli görüldügünde başvurulacak bir seçenek olarak kaldı. ${ }^{47}$

McNamara, 19 Ekim itibariyle Sovyet füzelerinin Küba'dan çıkarılması için ABD'nin bir bedel ödemesi gerektiği düşüncesindeydi. En azından Türkiye ve İtalya'daki füzelerden feragat edilmesi gerekiyordu ve ayrıca bu ülkelere daha fazla para ödemek zorunda kalınacaktı. Robert

\footnotetext{
${ }^{44}$ FRUS, Cuban Missile Crisis and Aftermath, p. 110-112.

${ }^{45}$ Stern, a.g.e., p. 58.

${ }^{46}$ https://microsites.jfklibrary.org/cmc/oct18/doc2.html (Erişim tarihi: 18.03.2021).

47 CIA, "Documents on the Cuban Missile Crisis", p. 193 ve https://www.cia.gov/ library/center-for-the-study-of-intelligence/csi-publications/books-and-monographs/ Cuban\%20Missile\%20Crisis1962.pdf (Erişim tarihi: 18.03.2021).
} 
Kennedy; "SSCB tehdidiyle karşı karşıya gelme, buna karşı koyma ve şu an bertaraf etmeye karar verildiği takdirde çocuklarımız ve torunlarımız için en iyi durumun gerçekleşeceği" düşüncesindeydi. ${ }^{48}$ Aynı gün SNIE 11-18-62 sayıl1 "Küba'da ABD'nin Hareketlerine Karşı Sovyet Tepkileri" başlıklı CIA değerlendirmesinde SSCB'nin Küba sürecini ABD ile başka pazarlıklarda koz olarak kullanmak isteyebileceği, ABD'nin adadaki Sovyet silahlanmasına sessiz kalması halinde başta Latin Amerika olmak üzere Amerikan karşıtı düşünceye güçlü bir dayanak sağlayacağı belirtilmişti. Uzun vadede ise ABD'ye duyulan itimat azalacaktı. Öte yandan Kruşçev'e geri çekilme konusunda baskı yapılsa dahi SSCB'nin konuşlandırmayı sona erdiremeyeceği, Kremlin'in SSCB, üs kurma konusunda eşit hak iddia edeceği ve Küba'yı Berlin konusuyla ilişkilendireceği de raporda yer alyyordu. ${ }^{49}$ Kennedy, Sorensen ve R. Kennedy'den abluka konusunda kurulun mutabakata varmasını istedi. McNamara açısından abluka kararının maliyeti İtalya ve Türkiye'deki füzelerden feragat edilmek zorunda kalınacak olmasıydı. Çünkü SSCB Küba'daki füzeler bu ülkelerdeki ABD füzelerine karşı pazarlık unsuru olarak kullanacaktı. ${ }^{50}$

Toplantıdan sonra SNIE 11-19-62 sayılı “ABD’nin Küba'ya Yönelik Eylemlerinin Basslıca Sonuçları (Major Consequences of Certain US Courses of Action on Cuba) başlıklı değerlendirilmesi yayınladı. Bu değerlendirmede 19 Ekim raporuna ek olarak SSCB'nin abluka karşısında ABD'ye nükleer füze kullanma seçeneğinden vazgeçmeyeceği ve Castro rejiminin çökmeyeceği görüşlerine yer verildi." ${ }^{51}$ McNamara, bu raporun ardından ablukanın avantaj ve dezavantajlarını sıraladı. Özgür dünyanın lideri olarak ABD'nin konumuyla uyumlu askerî eylem seçeneği ve Sovyetlerin genel savaşa yol açabilecek ani bir askerî hareketten imtina etmesi avantajdı. Dezavantaj ise füzelerin Küba'dan çıkarılmasının uzun bir süreç alacağı ve bunun da $\mathrm{ABD}$ 'de ciddi sorunlara yol açmasaydı. Hatta ABD'nin dünyadaki konumu zayıflayabilecekti. Kennedy, füze tehdidinin

\footnotetext{
${ }^{48}$ FRUS, Cuban Missile Crisis and Aftermath, p. 116-122.

${ }^{49}$ A.g.e., p. 122-123.

${ }^{50}$ Stern, a.g.e., p. 71-72.

${ }^{51}$ CIA, "Documents on the Cuban Missile Crisis", p. 211-220 ve https://www.cia.gov/ library/center-for-the-study-of-intelligence/csi-publications/books-and-monographs/ Cuban\%20Missile\%20Crisis1962.pdf (Erişim tarihi: 18.03.2021).
} 
gün geçtikçe dünyayı daha da felakete sürüklendiğini kabul ederek, geriye dönüp baktığında şu an yapılması düşünülen planın daha önce yapılmış olmasını istediğini söyledi. Rusk, ablukanın Küba'ya daha fazla füze girişini ciddi bir şekilde etkileyeceğini, çünkü SSCB'nin şu an orada bulunanlara ek olarak Küba'ya herhangi bir füze gönderemeyeceğini söyledi. ${ }^{52} \mathrm{McC}$ Cone açısından ise abluka yeterli bir seçenek oluşturmuyordu. Ablukanın başlamasıyla Sovyetlere füzelerin 72 saat içinde sökülmesi gerektiği, aksi durumda ABD'nin hava saldırısıyla füzeleri imha edeceğinin bildirilmesi gerekliydi. Taylor da sorunun ablukayla çözülemeyeceğini hatta füze tehdidini sona erdiremeyeceğini savundu. Sonunda askerî güç kullanmak zorunda kalınacaktı ve beklemenin daha kötü sonuçlara yol açacaktı. Dillon, Sovyetlerin hali hazırda Küba'daki füzeleri sökmeye razı olması halinde füzelerin yeniden kurulmamasını sağlamak için sürekli bir denetime ihtiyaç duyulması gerektiği fikrindeydi. Stevenson ise, Sovyetlere Türkiye'deki $\mathrm{ABD}$ füzelerinin çekilmesi ve Guantanamo üssünün boşaltılmasıyla ilgili bir anlaşma önerilmesi taraftarıydı. Kennedy, mevcut durumda Guantanamo'daki üssün kapatılmasına karşı çıktı. Böyle bir hareket dünyaya; "ABD korktu ve şu anki konumunu terk etmek istiyor" mesajını verecekti. ${ }^{53}$ Kennedy bu noktada tartışmalara ara verdi ve ablukaya geçilmesini veen geç 20 Ekim salı gününe kadar füze sahalarına ve füzelere saldırı yapılmak üzere gerekli önlemlerin alınması için hazır olunması düşüncesini açıkladı. Ayrıca, hazırlıklar için orduya izin vermeye hazır olduğunu ve İtalyanlara veya Türklere saldırıldığı takdirde sahip oldukları stratejik füzeleri ateşlememelerinin bildirilmesini önerdi. Rusk, hem müttefiklerle görüşmek hem de gereken zamanı elde etmek için pazartesiden önce ablukanın başlatılmaması düşüncesindeydi.

Krizin altıncı gününe (21 Ekim) gelindiğinde 11.30-12.30 arasında Oval Ofis'te tekrar toplantı yapıld1. McNamara, gece boyunca elde edilen bilgilere istinaden Küba'da yaklaşık 40 MRBM veya IRBM rampaları için donanımlar bulunduğunu bildirdi. McCone de bu bilgiyi teyid etti. ${ }^{54}$ Taktik Hava Komutanı General Walter Sweeney, Küba füzelerinin imhasına

\footnotetext{
${ }^{52}$ FRUS, Cuban Missile Crisis and Aftermath, p. 129-130.

${ }^{53}$ A.g.e., p. 132-134.

${ }^{54}$ A.g.e., p. 138.
} 
yönelik hava saldırısının teknik askerî boyutuna değindiğinde ordu Başkanın talimatı doğrultusunda hazırlıklarını tamamlamış görünüyordu. ${ }^{55}$ Bu noktada Kennedy, muhtemel hava saldırısı gerçekleştirmek için hazır olunması emrini verdiğinde kardeşi krizin nükleer bir savaşa dönüşmesi endişesini ortaya koyarken McCone de hava saldırısı sonrasında istila için hazırlıklı olunması gerektiğini söylemişti. ${ }^{56}$

Toplantının ardından Kennedy, 12:30'da İngiltere Büyükelçisi Ormsby Gore ile Beyaz Saray'da bir araya geldiğinde füzelerin ortadan kaldırması ya da adayı abluka altına almak için bir hava saldırısı seçeneğiyle belirterek İngiltere'nin hangi seçeneği destekleyebileceğini sordu. Gore, abluka seçeneği üzerinde durmuştu Başkan bu görüşmenin ardından Amerikan halkına yapacağı konuşmanın taslağı oluşturulmaya başladı. Kennedy açısından özellikle Sovyetlerin Küba'da gizli bir şekilde hareket ettiğinin vurgulanması önemliydi. Ancak toplantıda, ABD eyleminin abluka mı yoksa karantina mı olarak tanımlanması gerektiği tartışma konusu oldu. Rusk, hukuki açıdan iki kelimenin anlamı aynı olsa da hem Berlin ablukasıyla kıyaslanmasının önlenmesi hem de politik nedenlerden dolayı karantina kelimesinin kullanılmasını tercih ettiğini ifade etti. Kennedy Rusk ile aynı fikirde buluştu. ${ }^{57}$ Konuşma metni üzerindeki çalışmada Kennedy, Küba'daki tüm oluşumların sorumluluğunun doğrudan Kruşçev'e bağlanması gerektiği ve savaşın oluşturduğu korkuyu anlatan ifadelerin silinmesini ve Kruşçev'le zirve toplantısı davetinin silinmesine karar verdi. ABD müttefiklerinin gemilerinin ablukaya maruz kalıp kalamayacakları konusu gündeme geldiğinde Kennedy müttefik gemilerine de abluka

\footnotetext{
${ }^{55}$ A.g.e., p. 139. Buna göre angajman kurallarına da yer verilen muhtemel hava saldırısı şu şekilde gerçekleşecekti "Bilinen füze sahalarının yakınındaki 5 adet SAM tesisinin her biri takribi 8 uçak tarafindan saldırıya uğrayacak; füze alanların savunan 3 MIG havaalanı, 12 ABD uçă̆ıyla karşllanacak. Toplam olarak, gerekli yedek uçaklarla beraber savunma imha operasyonlart için yaklaşık 100 sorti yapılacak. 8 veya 9 bölgedeki toplamda yaklaşık 32 ilâ 36 rampalarn her biri 6 uçakla saldirlya uğrayacak ve bunun için için de yaklaşık 250 sorti yapılacak. Ayrıca 3 MIG havaalanını kapsayan ABD uçağı, havalanmalar durumunda MIG'lere saldıracak." Sweeney, hava saldırısının olumlu sonuçlar doğuracağı konusunda emindi: saldırıda füzelerin yüzde 90'ını yok edilecekti.

${ }^{56}$ A.g.e., p. $139-140$.

${ }^{57}$ A.g.e., p. $140-143$.
} 
uygulanacağını belirtti. Savunma Bakanlığı ayrıca İtalya ve Türkiye'den ABD füzelerini çekme sorununun incelemesi yönünde talimatlandırıldı. ${ }^{58}$

22 Ekim'de Başkan Kennedy, kriz için özel olarak Milli Güvenlik Konseyi İcra Kurulu'nu (The Executive Committee of the National Security Council/ ExComm) kurdu. ExComm, MGK'dan daha küçük bir gruptu ve aynı zamanda Başkan'a geçici olarak dışarıdan danışmanlar getirme esnekliği sağlıyordu. Kennedy'le birlikte toplamda 42 toplantı ve onun katılımı olmaksızın 2 ek toplantı yapıldı. Küba Krizi'ne çözüm bulmak için kurulan grup, Beyaz Saray'da Kabine Odası'nda toplandı. Bu toplantıların çoğu Kennedy tarafından kaydedildi. ${ }^{59}$ Ayrıca ExComm'un çalışmalarını kolaylaştırmak için departmanlar arası üç alt komite kuruldu. İlki Savunma Bakan Yardımcısı Paul Nitze başkanlığında, Berlin'deki acil durumlar üzerine çalışmaktaydı. İkincisi, Dışişleri Bakanlığı Politika Planlama Konseyi Başkanı Walt W. Rostow'un başkanlığında önceden planlama yapmaktaydı. Başkanlığını Dışişleri Bakan Yardımcısı William H. Orrick, Jr.'’n yaptığı üçüncü alt komite, bir krizin ihtiyaç duyacağı dünya çapında etkili bir iletişim sistemi kurmaya yöneldi. ${ }^{60}$

Günün ilerleyen saatlerinde CIA'nın “Küba'daki Sovyet Askerî Birikiminin Zamanlamas1 (Timing of the Soviet Military Buildup in Cuba) başlıklı bir muhtırasında 1 Ağustos itibariyle füze sistemlerinin konuşlandırılması çalışmaları başlamıştı. ${ }^{61}$ CIA'nın bu raporu Kennedy'de şaşkınlık yaratmış gibiydi. Kennedy aynı gün İngiltere Başbakanı Harold Macmillan tarafından gelen mesajı toplantıya katılanlara okuttu. Mesajda SSCB'nin Küba'ya nükleer füzeler konuşlandırdığı ve füzelerden bazılarının çoktan faal halde olabileceğine dair delillerin elde edildiği yazıyordu.

\footnotetext{
${ }^{58}$ A.g.e., p. 144-148.

${ }^{59} \mathrm{https} / / /$ historyinpieces.com/research/meetings-excomm-executive-committee-nationalsecurity-council (Erişim Tarihi: 20.03.2021).

${ }^{60} 11$ Ocak 1963'te Berlin Muhtemel Durumlar Alt Komitesi ve Ön Planlama Alt Komitesi Kennedy tarafından feshedildi. Bromley K. Smith, "Organizational History of the National Security Council during the Kennedy and Johnson Administrations", 1988, p. 46-47 ve https://historyinpieces.com/documents/files/2014/08/Smith-NSCHistory-1988.pdf (Erişim tarihi: 20.03.2021).

${ }_{61}$ CIA, "Documents on the Cuban Missile Crisis", p. 269 ve https://www.cia.gov/ library/center-for-the-study-of-intelligence/csi-publications/books-and-monographs/ Cuban\%20Missile\%20Crisis1962.pdf (Erişim tarihi: 19.03.2021).
} 
Macmillan, açıçca füzelerin geri çekilmesi gerektiğini belirterek bu talebi Moskova'ya iletme niyetinde olduğunu ifade ediyordu. Macmillan'ın müttefikinden talebi BM gözlemcilerinin gözetiminde Küba'da füze üsleri ve diğer taarruz silahlarının çekilmesi ve sökülmesi çağrısına BM'de destek vermesiydi. ${ }^{62}$ Küba Krizi salt Washington-Moskova kontrolünde olan bir süreç olmaktan çıkıyordu. Başkan Kennedy, R. Kennedy, McNamara, Rusk, Bundy ve Ball ile Küba konusunu konuşmak üzere 11.00-11.45 arasında bir araya geldiğinde Türkiye'deki füze sahalarında görevli personelin SSCB saldırısına uğramaları durumunda karşılık vermemeleri konusunda tekrar bilgi verilmesi gereğini vurguladı. Öte yandan Kennedy'nin krizle ilgili kamuoyunu bilgilendirme konuşmasının zamanlamasının ne olacağını konusunda Beyaz Saray 22 Ekim öğlen saatleri itibariyle hâlâ net bir karara varamamışt1. ${ }^{63}$ Amerikalı karar alıcılar 15.00'de yeniden bir araya geldiğinde Dışişleri abluka eyleminin en iyi hukuki dayanağının Rio Antlaşması olduğunu açıkladı. ${ }^{64} \mathrm{R}$. Kennedy ise OAS'tan destek gelmemesi durumunda ablukanın yasa dişı olabileceğini düşündüğünü ifade etti. Ona göre, OAS'ta, gerekli olan on dört lehte oyun alınması önemliydi. McCone ise istihbarat bilgilerini özetleyerek yedi gün içerisinde SSCB denizaltı filosunun Küba'ya ulaşabileceğini açıkladı. Açıklama ve tartışmalar sonrası Kennedy, halka ifade edilebilecek cevaplarla ilgili tavsiye istedi. $\mathrm{Bu}$ gelişmelerin bilindiği halde neden daha önce harekete geçilmediği sorusu önemliydi. Bu soruya cevap ise Küba'daki SSCB stratejik füzelerin mevcudiyeti hakkında daha fazla kanıta ihtiyaç duyulduğu olacaktı. Kennedy yapacağı konuşmada özellikle Berlin ablukasıyla Küba ablukası arasındaki ayrımın açık bir şekilde ortaya konulması gerektiğini,

\footnotetext{
${ }^{62}$ FRUS, Cuban Missile Crisis and Aftermath, p. 149-151.

${ }^{63}$ A.g.e., p. 151-152.

${ }^{64}$ Rio Paktı resmî adıyla 2 Eylül 1957 tarihli "The Inter-American Treaty of Reciprocal Assistance" (Inter-Amerikan Karșılıklı Yardım Anlașması. 2. Dünya Savașı sonrası yeni dünya düzeninde Batı Yarımküre'nin kollektif güvenliğinin sağlanması ve BM Sözleșmesi'nde belirtilen silahlı saldırıya uğranılması halinde kendini savunma hakkını ön plana çıkaran ABD liderliğinde Latin Amerika ülkelerinin imzaladığı pakttır. Pakta hâkim olan görüs kökenlerini 19. yy'dan o güne değin ABD'nin bölgede uyguladığ Monroe Doktrini'nden alır. Francisco V. Garcia-Amador, "The Rio de Janeiro Treaty: Genesis, Development, and Decline of a Regional System of Collective Security", University of Miami Inter-American Law Review, Number 1, Vol 17, Fall 1985, p. 1-42.
} 
Küba'ya ilaç ve yiyecek gönderilmesine engel olunmadığını yalnızca saldırı silahlarının Küba'ya gitmesinin önlediğinin vurgulanmasını istedi. ${ }^{65}$

Kennedy, ablukayı ve SSCB'nin Küba'da saldırı amaçlı füze konuşlandırmasını halka açıklamadan önce Kruşçev'e bir mesaj gönderdi. Mesajda Viyana'daki toplantıya atfen sorun ne olursa olsun çözüm için barışçıl müzakerelere başvuracağını fakat Küba'da istenmeyen gelişmeler olmasi durumunda ABD'yi ve müttefiklerini korumak amacıyla gereken her şeyin yapılacağı vurgusu vardı. Kennedy özellikle güç kavramını öne çıkarmıştı. ABD, Batı yarımkürenin güvenliğine yönelik mevcut tehdidi sonlandıracağına dair kararlılığını ortaya koyuyordu. Yine de çözüm odaklı öneriler sunan Başkan, Sovyetlerin bu krizi derinleştirmesi veya genişletmesinden kaçınmasını ifade ederek barışçıl müzakereler aracılığıyla bu meseleyi ortadan kaldırmasın 1 ifade etti. ${ }^{66}$

Kennedy 22 Ekim saat 19.00 'daki konuşmasında ABD halkına zorlu bir siyasi sürece hazırlanılması gerektiği mesajını verdi. Küba'daki gelişmelerin Washington'1, Mexico City'i, Cape Canaveral'ı, Panama Kanalı'nı veya Karayipler ya da ABD'nin güneydoğu kesimindeki başka bir şehri vurabileceğini açıkladı. Küba ve Sovyetler ABD için bir tehditti. Nükleer silahların önemini vurgulayan Kennedy, Amerikan Devletleri Örgütü altındaki İstişare Teşkilatı'nın hemen toplanması ve gerekli tüm eylemleri desteklemek için Rio Paktı'nın 6 ve 8 . maddelerinin $^{67}$ yürürlüğe girmesi ve $B M$ Tüzügü uyarınca Güvenlik Konseyi'nin dünya barışına yönelik bu SSCB tehdidine karşı harekete geçmek için acil toplanmasını isteyeceğini açıkladı. Bu ifadeler 2. Dünya Savaşı'ndan sonra ABD'nin mimari olduğu uluslararası sistemin Washington açısından diş politikada araçsal hale getirilmesini ifade ediyordu. ${ }^{68}$ Konuşma birçok Amerikalıyı paniğe sürükledi. On milyona yakın Amerikalı herhangi bir nükleer saldırıdan korunmak ve güvenli bir yer bulmak için yaşadıkları şehirlerinden

\footnotetext{
${ }^{65}$ FRUS, Cuban Missile Crisis and Aftermath, p. 152-155.

${ }^{66}$ FRUS, Kennedy-Khrushchev Exchanges, Volume VI, 1961-1963, p. 165-166.

${ }^{67}$ Rio Paktı maddeleri için bkz. http://www.oas.org/juridico/english/treaties/b-29.html (Erişim tarihi: 20.03.2021).

${ }^{68}$ Konuşmanın tam metni için "Radio and Television Report to the American People on the Soviet Arms Buildup in Cuba" https://microsites.jfklibrary.org/cmc /oct22/doc5.html (Erişim tarihi: 20.03.2021).
} 
ayrıld1. ${ }^{69}$ Halka hitap ettikten sonra Macmillan'la konuşan Kennedy, Küba'yı istila etme planının olmadığını belirterek yegâne politik amacının füzelerin Küba'dan çıkartılması olduğunu belirtti. ${ }^{70}$

Kennedy'nin abluka kararı Kongre'de hem Cumhuriyetçi hem de Demokrat liderler tarafindan desteklendi. Nixon; "Söz konusu sulh ve özgürlüğün tehdit edilmesiyse farklı partiler bir olur, öncelikle vatanı düşünürler” diyerek Demokrat başkanın kararının arkasında durduğunu ilan etti. Eski başkanlardan Truman, Amerikan halkını Kennedy'i desteklemeye çağırdı. Atlantik'in diğer yakasından da Kennedy'e destek geldi. İngiltere, bu kararı olumlu karşılarken, Batı Alman Hükümeti sözcüsü ile İtalya Başbakanı Amintore Fanfani de Kennedy'nin yanında olduklarını belirttiler. Abluka için Avrupa'da nadir de olsa farklı görüşler ortaya çıktı. İngiliz liberal sol Guardian gazetesi “Kennedy, ABD'nin ehemmiyeti için Küba'yı abluka altına alıyorsa benzer şekilde Sovyetlerin de ABD üssünün yer aldığ Türkiye'yi abluka altına alma hakkı olduğu"nu yazd1 $1{ }^{71}$ Krizin en çok ilgilendirdiği ülkelerden birisi olan Türkiye de ABD safında yer aldı. İsmet İnönü ve Cemal Gürsel, Sovyetlerin bu krizi Türkiye'nin sınırlarına çevirmeye çalışabileceğinden bahisle daima ABD'nin desteklenmesinden yana olduklarını ifade etti. ${ }^{72}$

SSCB Savunma Bakanı açısından ise Kennedy'nin konuşması seçim öncesi gerçekleştirilen bir gövde gösterisiydi. ${ }^{73}$ Kennedy'nin konuşmasına çok sinirlenen Kruşçev, füze sahalarının yapımı için çalışmaların daha da hızlandırılmasını, SSCB gemilerine, Kennedy'nin açıkladığı ablukayı görmezden gelmeleri talimatını verdi. ${ }^{74}$ Ertesi gün OAS Konseyi özel bir oturumda bir araya geldiğinde, Latin Amerika hükümetleri Küba'daki füzelerin geri çekilmesini istedi. Kimi ülkeler ise ABD'ye daha açık destek sağladı. Brezilya Devlet Başkanı João Goulart, SSCB’nin Brezilya üzerinden

\footnotetext{
${ }^{69}$ Stern, a.g.e., p. 92.

${ }^{70}$ FRUS, Cuban Missile Crisis and Aftermath, p. 164.

${ }^{71}$ Akis Mecmuası, Cilt XXVI, Say1 435, 1962, s. 16-17.

${ }^{72}$ A.g.y., s. 7-8.

${ }^{73}$ Michael Dobbs, Geceyarısına Bir Kala: Nükleer Savaşın Beşiğinde Kennedy, Kruşçev ve Castro, (Çev. Erhun Yücesoy), YKY, İstanbul, 2010, s. 53-54.

${ }^{74}$ Bruce, James G. vd., a.g.m., p. 155.
} 
Havana'ya kargo göndermesinin önlemesi için emir verdi. Arjantin ve Dominik Cumhuriyeti ise ABD donanmasına destek sağlayacağını açıkladı. ${ }^{75}$

OAS oturumunun ardından ExComm'un ilk toplantısında Kennedy, Küba'ya gidecek saldırı silahların engellenmesiyle ilgili planı onayladı. Buna göre bildiri 18.00 'de yayınlanacak ve 24 Ekim'de yürürlüğe girecekti. Kennedy, buna ek olarak orduda görev sürelerinin uzatılmasına izin veren bir başkanlık emrini ve U-2 uçuşlarını etkileyen bir sorun olması durumunda acil durum planını onayladı. ${ }^{76} \mathrm{Bu}$ sırada Kruşçev, bir gün önce Kennedy'nin yazdığı mektuba cevap vermiş ve mektubun tehdit içerikli olduğunu ifade etmişti. Kruşçev cevaben, Küba'daki füzelerin sadece savunma amaçlı olduğunu, ABD'nin dünya çapında yıkıcı sonuçlara yol açacak eylemlerden uzak durması gerektiğini belirtmişti. ${ }^{77}$ Bu sırada BM Güvenlik Konseyi de aynı günkü gergin geçen toplantıda ABD SSCB'nin dünya hâkimiyetine dair planının kanıtı olan Küba'daki füzeleri kınadı. SSCB de, ABD suçlamalarını kabul etmeyerek Küba'ya yalnızca savunma amaçlı silahların gönderildiğini açıkladi. $^{78}$

Konseyin toplanmasından sonra 18.00 'de yapılan ExComm toplantısında abluka ilanı Kennedy tarafindan imzalandı ve Kruşçev'in mektubu ele alınd1. ${ }^{79}$ Washington'un Moskova'ya mesajı karşılıklı anlaşma yolunda baskıcı politikanın terk edilmesi ve silahların geri çekilmesi gerektiğiydi. ${ }^{80} \mathrm{R}$. Kennedy, toplantı sonrası ilerleyen saatlerde Başkanın emri üzerine Büyükelçi Dobrynin'le bir araya geldi. R. Kennedy'nin Küba'da bulunan füzeleri kınaması üzerine Dobrynin, saldırı füzeleri hakkında hiçbir bilgisinin olmadığını açıkladı. Dobrynin, konuşmanın ardından, Başkan Kennedy'nin kandırılmış hissettiğini ifade eden telgraf Kremlin'e gönderdi. ${ }^{81} 24$ Ekim ExComm toplantısında Kennedy, Hazine Bakanı ve CIA Direktörü'nün daha fazla kara kutu (black boxes) almak için hemen

\footnotetext{
75 Tanya Harmer, "The Cuban Question And The Cold War In Latin America: 19591964", Journal of Cold War Studies, 2019, 21(3), 114-151, p. 139.

${ }^{76}$ FRUS, Cuban Missile Crisis and Aftermath, p. 168-169.

${ }^{77}$ FRUS, Kennedy-Khrushchev Exchanges, p. 166-167.

${ }^{78}$ Stern, a.g.e., p. 99.

${ }^{79}$ FRUS, Cuban Missile Crisis and Aftermath, p. 173.

${ }^{80}$ FRUS, Kennedy-Khrushchev Exchanges, p. 168.

${ }^{81}$ Stern, a.g.e., p. 107.
} 
harekete geçmesini emretti. Toplantının ortalarına doğru, bazı SSCB gemilerinin durduğu ve geri döndügüne dair bilgiler geldi. ${ }^{82} 11.24$ 'te Ball'ın hazırlayıp Rusk'ın onayladığı bir mesaj, ABD'nin Türkiye Büyükelçisi Raymond Hare ve ABD'nin NATO Büyükelçisi Thomas Finletter'e iletildi. Mesajda Küba'daki tehdidin çözümü için Türkiye'deki Jüpiter füzelerinin sökülmesinin gerekebileceği belirtildi. Bundan dolayı ABD-Türkiye ilişkilerine zarar gelmemesi için acil bir durum emrine karşı dikkatli şekilde hazırlanılması gerektiği belirtiliyordu. ${ }^{83} \mathrm{Bu}$ arada, BM Genel Sekreteri U Thant, hem Kennedy hem de Kruşçev'e durumu zorlaştıracak ve savaş riski oluşturacak muhtemel bir eylemden kaçınmaları yönünde mesaj yolladı. Mesajda tarafların mevcut krizi barışçıl bir şekilde sonlandırma ve Karayipler'deki durumu normale döndürmek amacıyla bir araya gelmeleri için tarafların birbirine zaman tanımasını istedi. ${ }^{84}$ SSCB'nin iki-üç hafta içinde silah sevkiyatlarını durdurmasını ve bu süre zarfında ABD'nin de karantinayı askıya almasını istedi. Ancak Washington BM Genel Sekreter'in bu teklifini kabul edilemez buldu. ${ }^{85}$

Gün içerisinde Kennedy'nin bir gün önce yazdığı mektuba Kruşçev'in cevabı Washington'a ulaştı. Sitemkâr bir dille kaleme alınan mektupta Kennedy'nin karantina ilan etmediğini, bilakis bir ültimatom ortaya koyduğu ve kuvvet kullanmakla tehdit ettiği belirtiliyordu. Ayrıca OAS'in, Kennedy'nin karar almasında hiçbir yetkiye sahip olmadığı, bundan dolayı bu kararların Moskova tarafından tanımadığı vurgulanıyordu. Mesajında kızgınlığını gizleyemeyen Kruşçev, ABD’nin bu eylemlerinin haydutluk ve dejenere emperyalizmin çılgınlığını oluşturduğunu, gelişmiş silahların ortaya çıkmasıyla beraber ABD'nin eski izolasyonunu tümüyle kaybettiğini ve bu aptallık için acı çekmesi gerektiğini ifade ediyordu. ${ }^{86} 25$ Ekim'de istihbarat brifinginde Kennedy, McCone'dan Küba'daki süreç hakkında dikkatli bir analiz hazırlamasını istedi. Ayrıca bir gün önce $U$ Thant'in gönderdiği mektuba verilecek cevabın bir versiyonunu da onaylandı. Toplantıda ayrıca yakın gelecekteki alternatif eylemler hakkında ön tartışma gerçekleştirildi.

\footnotetext{
${ }^{82}$ FRUS, Cuban Missile Crisis and Aftermath, p. 179.

${ }^{83}$ A.g.e., p. 180-181.

${ }^{84}$ A.g.e., p. 183.

${ }^{85}$ Freedman, a.g.e., p. 204.

${ }^{86}$ FRUS, Kennedy-Khrushchev Exchanges, p. 169-170.
} 
Başkan, bir sonraki toplantıda tartışlmak üzere alternatif eylemleri hazırlamak için çalışma yapılmasını istedi ${ }^{87} \mathrm{Bu}$ sırada Kruşçev'in mektubu Kennedy'e ulaşmış, Kennedy de ABD'nin haklı olduğunu ifade ettiği cevabi bir mektup yollamıştı. Mektupta Ağustos'ta Sovyetlerin Küba'ya askerî malzemeler ve teknisyenlerin gönderildiğine dair önemli raporların olduğu, Eylül başında da ABD'nin herhangi bir saldırı silahı sevkiyatını önemli bir konu olarak kabul edeceği belirtiliyordu. Mektupta mevcut oluşumun ortadan kaldırılması için Sovyetlerden gerekli önlemleri alması isteniyordu. ${ }^{88}$ Kruşçev'den sonra U Thant'in mektubuna karşıllk veren Kennedy, Küba'daki silahların kaldırılmasıyla bu sorunun çözüme kavuşacağını vurguladı. Washington'da bu gelişmeler yaşanırken Kruş̧̧ev de Kremlin'deki toplantıda çözümün füzelerin sökülmesine karşılık ABD'nin Küba'yı işgal etmeme sözü vermesi gerektiğini söylüyordu. ${ }^{89}$ Krizin en üst seviyelere ulaştığı ve dünyanın nükleer savaşın eşiğine geldiği günlerde ExComm da neredeyse sürekli toplantı halindeydi. Aynı gün ExComm 17.00'deki toplantısında Rusk, U Thant'ın BM önderliğinde ABD-SSCB görüşmelerine yönelik önerisinin Zorin'i sinirlendirdiğini fakat Kruşçev'in öneriyi kabul ettiğini bildirdiğini söyledi. ${ }^{90}$ Öğleden sonra Stevenson ve Zorin BM Güvenlik Konseyi'nde ${ }^{91}$ bir araya geldiklerinde Stevenson, Sovyetler Birliği'nin Küba'ya saldırı füzeleri konuşlandırıldığını kabul etmesi yönünde Zorin'e bask1 yaptı. Zorin'in cevab1 tecrübeli diplomatın kariyerine yakışacak bir ustalıktaydı: "Ben şu an bir ABD mahkemesinde bulunmuyorum ve dolayısıyla bu soruya cevap vermek istemiyorum." Stevenson sorgu hâkimliği görevine devam etti ve Sovyet temsilciye dünya önünde bir mahkemede bulunduğunu cevabının "evet ya da hayır" olabileceğini belirtti. "Zamanı gelince elbet bunun cevabın alacaksını" diyen Zorin karşısında Stevenson "Cehennem buz tutana kadar cevabinız beklemeye hazırım” karşılığını verdi. Küba'daki füzelerin U-2 fotoğraflarını Konsey

\footnotetext{
${ }^{87}$ FRUS, Cuban Missile Crisis and Aftermath, p. 202.

${ }^{88}$ FRUS, Kennedy-Khrushchev Exchanges, p. 171.

${ }^{89}$ Robert Dallek, An Unfinished Life: Fohn F. Kennedy, p. 564.

${ }^{90}$ FRUS, Cuban Missile Crisis and Aftermath, p. 204-205.

91 Dobbs'a göre burası rakibi zor sorularla köşeye sıkıştırmak için muazzam bir zemindir. Burada küllerinden yeniden doğmuş olan bir anka kuşu resmi bulunmaktadır. $\mathrm{Bu}$ resim, İkinci Dünya Savaşı'nın yıkılışı sonrası yeniden canlanan insanlığı temsil etmektedir. Ayrıca bkz. Michael Dobbs, a.g.e., s. 169.
} 
önünde sergileyen Stevenson Sovyetlerin Küba'da füze bulundurmadıkları yönündeki tezini de çürütmüştü. ${ }^{92}$

Bu sırada, Türkiye'ye füzelerin kaldırılmasıyla ilgili mesaja Ankara Büyükelçisi Finleter, 25 Ekim'de cevap verdi. Mesajda Türkiye'nin, Jüpiter füzelerini, Sovyet saldırılarına karşı nükleer silah kullanma kararlılığının bir simgesi olarak gördüğü ve bu füzelerin eskimiş veya savunmasızoldukları gerçeğinin şu anki Türk düşüncesini etkilemediği belirtiliyordu. ${ }^{93}$ Mesajın iletilmesinin ardından ExComm'ın Planlama Alt Komitesi tarafından "Kısa Vadede Sovyet Taktikleri" başlıklı bir rapor hazırlandı. Raporda, Sovyetler Birliği'nin ilk hedefinin Küba'daki üslerini muhafaza etmek olduğu ve bu tesisleri sadece askerî bir değer olarak değil aynı zamanda dünyadaki güç dengesinde yıllardır süregelen değişimin bir göstergesi olarak gördüğü belirtiliyordu. Bundan dolayı Sovyetlerin, süratli bir şekilde ABD'yi sert eylemlerden caydırmaya çalıştığı ve bu amaç doğrultusunda öncelikli Sovyet stratejisinin ABD'yi müzakerelere çekmek olduğu, bunu başarmaları halinde ABD'nin eylemlerine mâni olabileceklerini ve şu anki üslerin statükonun bir parçası haline gelebileceğini hesapladıkları hususlarına yer veriliyordu. ${ }^{94}$ Krizin son safhalarına yaklaş1lırken 26 Ekim'de CIA, "Küba'daki Sovyet Füze Değerlendirmesi" (Foint Evaluation of Soviet Missile Threat in Cuba) başlıklı notunda bir gün önce çekilmiş olan fotoğrafların analizinden MRBM alanlarının yapımlarının hızlı bir şekilde ilerlediği ve bu inşaatın kısa sürede tam operasyonel hale gelebileceği belirtildi. ${ }^{95} \mathrm{CIA}$, daha sonra "Kriz, SSCB/Küba" (The Crisis USSR/Cuba) başlıklı bir memorandum yayınladı. Son belgede bir önceki nota ek olarak herhangi bir rampa veya füze emaresine rastlanılmadığı, Küba'ya doğru seyreden iki SSCB yük gemisi ve beş tankerden sadece birisinin karantina hattını geçtiği ve üç gün önce toplam 16 kuru yük gemisinin Sovyetler Birliği’ne döndüğü belirtiliyordu. ${ }^{96}$ CIA raporunun ardından ExComm

\footnotetext{
${ }^{92}$ Dallek, a.g.e., p. 564-565.

${ }^{93}$ FRUS, Eastern Europe; Cyprus; Greece; Turkey, p. 731.

${ }^{94}$ FRUS, Cuban Missile Crisis and Aftermath, p. 216-217.

95 CIA, "Documents on the Cuban Missile Crisis", p. 314 ve https://www.cia.gov/ library/center-for-the-study-of-intelligence/csi-publications/books-andmonographs/Cuban\%20Missile\%20Crisis1962.pdf (Erişim tarihi: 21.03.2021).

96 CIA, "Documents on the Cuban Missile Crisis", p. 315 ve https://www.cia.gov/ library/center-for-the-study-of-intelligence/csi-publications/books-and-
} 
yeniden bir araya geldi. McNamara, füze alanlarındaki inşaatın devam ettiğini, hava gözetiminin devam etmesi hakkında kamuoyuna yapılmasını ve bu gece için keşif görevine çıkılması gerektiğini söyledi. Rusk ise BM Genel Sekreteri'nin müzakerelerinde olumsuz etki yaratmaması için gözlem uçuşlarının yapılmamasını istedi. Kennedy, Rusk'ın tavsiyesine uydu ve gece uçuşlarını kısa süreliğine erteledi. McCone, SSCB füzelerinin Küba'dan ayrılıncaya kadar karantinaya devam edilmesi gerektiğini vurguladı. Kennedy, füzelerin yalnızca karantinayla geri çekileceği konusunda şüpheliydi ve Küba'daki füzelerin ya Küba'ya saldırarak ya da anlaşma yapılarak çıkarılabileceğine inanıyordu. ${ }^{97}$ Öğleden sonra ABC News Muhabiri John Scali, Sovyet Büyükelçiliği Halkla İlişkiler Danışmanı ve Washington'daki KGB şefi olan Alexander Fomin'in acil ricası üzerine Washington'da restoranda bir araya geldiklerinde uluslararası krizlerde istihbarat örgütlerinin farklı bir yönü ortaya çıtı. Fomin, ABD’nin Küba'ya saldırmama taahhüdü karşısında $\mathrm{BM}$ yetkililerince doğrulanmak üzere Küba'daki füzelerin çıkarılmasına olumlu yaklaşılabileceğini açıkladı. Scali, bu teklifi Dışişleri Bakanlığı'na bildirdi. Rusk, Beyaz Saray'dan onayı aldı fakat yine de Fomin'e zamanın sona erdiğinin söylenmesini istedi. ${ }^{98}$ Günün sonuna yaklaşıldı̆̆ında Stevenson, 17.16 'da U Thant'le görüştüğünde 48 saat içinde silahların olduğu gemilerin artık Küba'ya gönderilmemesi, füze sahalarındaki çalışmaların sona erdirilmesi ve bu sahaların çalışmaz duruma getirilmesi yönündeki $\mathrm{ABD}$ görüşünü $\mathrm{BM}$ Genel Sekreteri'ne iletti. U Thant, Havana'nın ya da Moskova'nın bu istekleri kabul edeceklerine inanmasa da ABD'nin Küba'ya herhangi bir saldırı girişiminde bulunmayacağını garanti etmesi karşılığında füzelerin Küba'dan çıkarılacağına dair bir anlaşmaya varılabileceğinden ümitli olduğunu ifade etti. $^{99}$ İlerleyen saatlerde Kennedy, Macmillan ile telefon görüşmesinde Stevenson'ın BM Genel Sekreteri'ne ilettiği öneriler ve karantinanın devamlılı̆̆ hakkında konuştu. Macmillan ise, SSCB'nin Türkiye ve

monographs/Cuban\%20Missile\%20Crisis1962.pdf (Erişim tarihi: 21.03.2021).

${ }^{97}$ FRUS, Cuban Missile Crisis and Aftermath, p. 221-226.

98 Küba Krizi ile ilgi kitabında Sheldon Stern, Fomin'in Kruşçev adına öneri yapmadığını söz konusu girişimin özel bir KGB operasyonu ihtimali olduğunu iddia etti. Stern, a.g.e., p. 143.

99 Ernest May ve Philip Zelikow, Kennedy Tutanaklar ve Türkiye Üzerine Gizli Pazarlıklar, (Çev. Mehmet Harmanc1), Sabah, İstanbul, 1998, s. 342. 
İtalya'daki ABD füzeleri hususunda 1srarcı olabilecekleri kanaatindeydi. ${ }^{100}$ Telefon görüşmesinden sonra 19.00 'da Kruşçev'in mesajı geldi. Dört bölüm halindeki oldukça uzun olan Kruşçev'in telgrafının gelmesi neredeyse yedi saati buldu. ${ }^{101}$ Kruşçev mesajında savaşın sıfır toplamlı bir oyun olduğunu ayrıntılı olarak ifade etti. Israrla Küba'daki füzelerin savunma amaçlı olduğunu sergilese son mesajında daha öncekilerine göre daha 1lımlı bir hava hâkimdi. Nihai karar alıcı olarak Kruşçev, karar alma süreci ve dış politikasını etkileyen faktörleri değerlendirip ABD-SSCB ilişkisini normale döndürmek istediğini belirtti. Küba'nın hiçbir zaman ABD’ye saldırmayacağını, böyle düşünmenin bile imkânsız olduğunu vurgulayan Kruşçev, müzakerelere katılmaya istekli olduğunu ve oluşan gergin ortamın sona erdirilmesi gerektiğini vurguladı. ${ }^{102}$ ABD'ye zeytin dalı uzatan Kruşçev; ABD’nin Küba'ya saldırmama taahhüdüyle Sovyet Birliği'nin Küba'ya silah gönderiminin durdurulmasının birleşmesiyle nükleer savaş dügümünün en sonunda çözüleceğine inanıyordu. ${ }^{103}$ Aynı gün Ankara Büyükelçisi Hare, merkezine gönderdiği füze değerlendirmesiyle ilgili telgrafında Jüpiter füzelerinin Türkiye'den çekilmesinin sadece ikili ilişki bağlamında değil NATO'yla olan ilişkide de sorunlar doğuracağını belirtti. ${ }^{104}$ $\mathrm{Bu}$ anlarda Scali, akşama doğru yeniden Fomin'le görüsserek Rusk'ın mesajını iletti. Kennedy ve ExComm, Fomin'in önerisinin Kruşçev'in mesajıyla bağlantılı olduğu ihtimali üzerine hareket etmeye başlamıştı. ${ }^{105}$ Gece yarısı olduğunda Dobrynin R. Kennedy'le görüşmesinde, Küba'daki görüşmesinde füzelerin arkasında dururken ABD'nin de Türkiye'de füzeler bulundurduğuna işaret etti. R. Kennedy, krizin çözümü için bu aşamada Türkiye'deki füzeleri ön plana çıkarttı. ${ }^{106} \mathrm{Bu}$ sırada Planlama Alt Komitesi tarafından hazırlanan bir muhtırada, füzelerin Küba'dan çıkarılmasını garanti altına almak için müttefiklerin veya ABD'nin çıkarlarının takas

\footnotetext{
${ }^{100}$ FRUS, Cuban Missile Crisis and Aftermath, p. 244-246.

${ }^{101}$ May ve Zelikow, a.g.e., s. 347.

${ }^{102}$ FRUS, Kennedy-Khrushchev Exchanges, p. 172-177.

${ }^{103}$ Stern, a.g.e., p. 147.

${ }^{104}$ Öner Pehlivanoğlu, Küba Krizi ve Nükleer Savaş Eşiğinde Türkiye, Kastaş Yayınları, İstanbul, 2003, s. 120.

${ }^{105}$ Stern, a.g.e., p. 147.

${ }^{106}$ A.g.e., s. 123.
} 
edildiği düşüncesinden kaçınılması gerektiği uyarısı yer aldı. ${ }^{107}$ İki süper güç arasında krizin sona erdirilmesiyle ilgili zemin oluşmaya başladığı esnada Castro'nun Kruşçev'e gönderdiği bir mektup Küba liderinin krizin tırmanmasını neden olabilecek bir yaklaşıma sahipti. Castro muhtemel bir saldırıyı yirmi dört ila yetmiş iki saat içerisinde olabileceğini düşünüyordu. Buna göre ya füzelerin yok edilmesine yönelik hava saldırısı veya istila harekâtı olacaktı. ${ }^{108}$ Tedirginliği artmıs olan Castro, Küba hava savunma birliklerine, ABD keşif uçaklarına ateş açmak için hazır bulunmalarını emretti. ${ }^{109}$

Krizin on ikinci günde CIA'in 27 Ekim tarihli krizle ilgili bir değerlendirmesinde 25 Ekim itibariyle Sovyetlerin inşaatı durdurma veya sökme amacıyla ilgili herhangi bir emare olmadığı belirtiliyordu. Altı MRBM sahasından beşi tam anlamıyla operasyonel kapasiteye sahipti, altıncısının ise 28 Ekim'de tam olarak faaliyete geçecekti. Bu süre zarfında yeni füze alanları tespit edilmemişti. Bunlara ek olarak San Cristobal'daki dört MRBM alanından üçü ve Sagua La Grande'deki iki alan da faaldi. ${ }^{110}$ CIA memorandumundan sonra kiriz süresince mutat hale gelen ExComm toplantısı 10.00'da başladı. Küba'ya doğru seyir halindeki Sovyet gemilerinin konumlarını bildirerek biri sabah diğeri öğlen olmak üzere iki gündüz keşif görevi önerisini Başkan onayladı. Toplantı gündemi Türkiye'deki Jüpiter Füzelerine geldiğinde Nitze füzeleri sökme girişimine Türkiye'nin göstereceği tepkisinin çok sıkıntılı olacağını dile getirdi. Ball'a göre, Türklere göre İtalyanları ikna etmenin daha basitti. Rusk'a göre ise Türkiye'deki füzeler Küba'dakilerden ayrı tutulmalı, Varşova Paktı ve NATO bağlamında ele alınmalıydı. Bundy açısında ABD'nin çıkarları için bir müttefiki satacak konuma girilmemesi önemliydi. Kennedy, Türkiye konusunun

\footnotetext{
${ }^{107}$ FRUS, Cuban Missile Crisis and Aftermath, p. 249-250.

108 "Letter from Fidel Castro to Khrushchev", 26 October 1962, https://microsites.jfklibrary.org/cmc/oct26/doc2.html (Erişim tarihi: 24.03.2021).

${ }^{109}$ Lawrence Freedman, a.g.e., p. 220.

110 CIA, "Documents on the Cuban Missile Crisis", p. 324-328 ve https://www.cia.gov/ library/center-for-the-study-of-intelligence/csi-publications/books-and-monographs/ Cuban\%20Missile\%20Crisis1962.pdf (Erişim tarihi: 24.03.2021) ve https://www.cia.gov/ library/center-for-the-study-\%20of\%20intelligence/csi-publications/books-andmonographs/Cuban\%20Missile\%20Crisis1962.pdf (Erişim tarihi: 24.03.2021).
} 
kapatılıp yeniden Küba meselesine odaklanılması isteyerek en kısa sürede füze alanlarındaki inşaatın durdurulması gerektiğini açıkladı. ${ }^{111}$

Washington'a ulaşan 27 Ekim tarihli Kruşçev'in mesajı SSCB'nin krizi sona erdirme isteğini yansitıyordu. Mesaj Türkiye, İngiltere ve İtalya'da bulunana füzeler arasında Türkiye'nin Sovyetler Birliği'ne yakın konumda olduğu belirtilere konunun BM'de gündeme gelmesi ve orada söz verilmesi kaydıyla Küba'daki füzelere karşıllk Türkiye'deki füzelerin sökülmesini öneriyordu. ${ }^{12}$ Kennedy ve kurmayları Kruşçev'in teklifini olası bir anlaşmaya varmak ve nükleer değişimin doğuracağ 1 askerî harekâtlardan kaçınmak için son şans olarak değerlendirdiler. Fakat Kennedy yönetimi Türkiye'deki füzelerin Küba'daki füzelere karşılık pazarlık unsuru haline getirilmesinin NATO'yu baltalayacağını ve ABD'nin, müttefiklerinin müdafaası için risk almaya isteksiz olduğu düşüncesini arttıracağ düşüncesindeydi. ${ }^{113}$ Yine de Kennedy, Türkiye'deki füzelerin askerî açıdan değerinin çok az olduğunu ve bu durumun Küba veya Berlin'de savaşa yol açabileceği kanaatindeydi. ${ }^{114}$ NATO ittifakının ortaklık değerlerinin korunmasının önemiyle küresel çatışma riski arasında tercih yapmak Kennedy yönetimi için bir ikilem haline gelmişti.

ExComm, gelişmeleri değerlendirmek üzere 16.00 'da yeniden toplandığında R. Kennedy, Başkan'ın Kruşçev'e göndereceği mektupta Türkiye'den söz edilmemesini ${ }^{115}$ sadece SSCB füzelerinin çıkarılması durumunda Küba'yı işgal etmemeye garanti verileceğinin yazılmasını önerdi. O sırada Rusk, bir keşif uçağının seyir hatası nedeniyle yanlışlıkla SSCB hava sahasına girdiğini bildirdi. Kennedy, bu gelişmeyi topluma açıklamama kararı aldı fakat SSCB'nin olayı duyurmasının ardından

\footnotetext{
${ }^{111}$ FRUS, Cuban Missile Crisis and Aftermath, p. 252-256.

${ }^{112}$ FRUS, Kennedy-Khrushchev Exchanges, p. 178-181.

${ }^{113}$ Dallek, a.g.e., p. 567.

${ }^{114}$ Stern, a.g.e., p. 156.

115 Robert Kennedy, Kruşçev'in 26 Ekim'de yolladığ düşündü. $\mathrm{Bu}$ aslında bilerek düşünülmüştü. Çünkü ABD’nin zaman kazanması gerekiyordu. İki ülke arasındaki füzelerin takas edilmesinin yazıldığı mektubun varlığından haberdar olunmamış gibi davranılacaktı. Ve bu diplomatik strateji "Trollope Ploy" olarak adlandırılmaya başlandı. Ayrıca bkz. Turan Yavuz, Satılık Müttefik: Gizli Belgeler Işı̆̆ında 1962 Küba Füze Krizi ve Türkiye, Destek Yayınları, İstanbul, 2019, 175 ve Sheldon Stern, a.g.e., p. 134.
} 
ABD'nin de açıklama yapmak için hazırda bulunmasını istedi. Ancak işler bu nokta ABD'nin kontrolünden çıkmıştı. Taylor, U-2'nin vurulduğunu ve pilotunun öldüğünü söyledi. ${ }^{116}$ Pentagon mevcut gelişme karşısında Küba'nın işgali için hazır olunması gerektiğine inanıyordu. Pentagon'un işgal baskısına rağmen krizin sona ermesi için son bir adım kaldığına inanan Kennedy, generalleri sakinleştirmede zorlanma pahasına karantinanın devam etmesini istedi. ${ }^{117}$ Toplantıda konu yeniden Türkiye'deki füze meselesine geldiğinde komite üyeleri füzelerin sökülmesinin bir Türk sorunu yaratacağında hemfikirdiler. Kennedy bu noktada füzelerle ilgili Türklerle müzakerelere başlanması gerektiğinde ısrarcıydı. Bundy, bu konunun birçok kişi tarafindan ticaret olarak anlaşılacağını ifade etti. Kennedy açısından ise en iyi yol, aslında herhangi bir soruna yol açmadan Türkiye'nin kendi rızasıyla füzelerin geri çekilmesini teklif etmesiydi. Soruna çözüm bulma konusunda McNamara yeni bir öneri sundu: ABD'nin Küba'ya saldırma ihtimaline karşı saldırı gerçekleşmeden önce güvenliğin arttırılması için eskimiş Jüpiterler yerine Polaris denizaltılarının devreye sokulması. Ancak Kennedy'e göre bu durumda Türkiye'nin olumlu cevap vermemesi durumunda ortaya çıkacak tehlikeyi otomatik olarak kabul ettikleri anlamı çıkacaktı. 25 Ekim ExComm toplantısından da Türkiye sorununa nasıl çözüm bulunacağı karara varılamamışt1. ${ }^{118}$

Toplantı sonrası Kruşçev'e iletilen mesajda Küba'daki saldırı füze üslerinin inşaatının durdurulması, adadaki saldırı yeteneğine sahip bütün silah sistemlerinin BM gözetimi altında etkisiz hale getirilmesi ve Küba'dan çıkarılıp bir daha bu tür silah sistemlerinin girişinin engellenmesi gerektiği vurgulandı. ABD'nin karşılık olarak karantinayı kaldıracak, Küba'yı işgal etmemek içinse güvence verecekti. ${ }^{119}$ Mesaj gönderildikten sonra 21.00'de ExComm yeniden topland1. Bu arada Kennedy ve Rusk, toplantıdaki diğer yetkililerin haberi olmadan Türkiye-Küba takasını kolaylaştıracak bir plan hazırlamışlardı. Rusk, Kennedy'nin isteği üzerine, eski BM Genel Sekreter Yardımcisı Andrew Cordier'e telefon ederek U Thant'e iletilmek üzere bir mesaj yazdırdı. Mesajda U Thant aracılığıyla Türkiye-Küba takasını

\footnotetext{
${ }^{116}$ FRUS, Cuban Missile Crisis and Aftermath, p. 264-267.

${ }^{117}$ Yavuz, a.g.e., s. 181.

${ }^{118}$ Stern, a.g.e., p. 174-177.

${ }^{119}$ FRUS, Kennedy-Khrushchev Exchanges, p. 181-182.
} 
gerçekleştirilmesi öngörülüyordu. ${ }^{120} \mathrm{Bu}$ sırada R.Kennedy ve Dobrynin arasında Adalet Bakanlığı'ndaki görüşmede SSCB'nin ABD'nin Küba'ya saldırmama sözü vermesi karş1lığında $B M$ gözetimi altında Küba'daki füzeleri çekme kararı alındı. ABD'de ek bir gizli anlaşmanın da dâhil edilmesiyle, Türkiye'deki füzeleri çıkarmayı kabul etti. ${ }^{121}$

28 Ekim, Kruşçev'in krizi bitiren mesajının 09.00'da Moskova radyosunda yayınlanmasıyla başladı. Sovyet spikerin yaklaşık on beş dakika boyunca okuduğu metnin içeriği Kruşçev'in Kennedy'e gönderdiği mektuplardan farklı değildi. Spiker yayını “Küba'daki füzelere karşıllk olarak Türkiye'deki füzeler..." cümlesiyle sonlandırd1. ${ }^{122}$ Castro, füzelerin söküleceğini Revolución'un editörü Carlos Franqui'den öğrendiğinde Vedado'daki evindeydi. ${ }^{123}$ Castro'nun buna tepkisi ABD U-2 uçaklarını düşürülmesi emri oldu. Fakat o gün San Antonio Hava Üssü'nden hiçbir ABD keşif uçağı havalanmadı. ${ }^{124}$ Bunun üzerine Kruşçev, Castro'ya 27 Ekim'de Kennedy'e gönderilen mesaj sayesinde, mevcut durumu komünist lehine çevirmeyi ve Küba'nın muhtemel bir işgalden korunduğunu iletti. Kennedy ABD'nin Küba'yı hem kendi güçleriyle hem de müttefikleriyle beraber işgal etmekten kaçınacağına dair teminat vermişti. Kruşçev Castro'dan bir anlık sinirle herhangi bir şey yapmamasını fakat bir saldırı durumunda emrindeki bütün güçlerle önlem alabileceğini belirtti. Kontrol bu anlamda Kremlin'deydi ve bu Castro'ya açıkça belirtilmişti: “Biz kendi açımızdan, Küba'daki durumu istikrara kavuşturmak, Küba'yı işgalden korumak ve sosyalist bir toplumun barışçl bir şekilde inşa edilme ihtimalini korumak için elimizden geleni yapryoruz." 125 Havana'daki Sovyet Büyükelçiliği'ne ulaşan mektubu Castro'ya vermek isteyen Alexander Alekseyev, Castro'nun şehri terk ettiğini öğrendi. Castro, aslında o sırada El Chico'daki Sovyet askerî karargâhından son durumla ilgili daha fazla

\footnotetext{
${ }^{120}$ Pehlivanoğlu, a.g.e., s. 134.

121 "Meeting of Robert Kennedy and Dobrynin", 27 October 1962, https://microsites.jfklibrary.org/cmc/oct27/ (Erişim tarihi: 25.03.2021).

122 Yavuz, a.g.e., s. 153-154.

${ }^{123}$ Dobbs, a.g.e., p. 417.

${ }^{124}$ Pehlivanoğlu, a.g.e., s. 136.

125 "Letter from Khrushchev to Fidel Castro", 28 October 1962; https://digitalarchive. wilsoncenter.org/document/114504.pdf?v =45584ab0dfdce9395b29471\%20df701c9bc (Erişim Tarihi: 26.03.2021).
} 
bilgi almaya çalışıyordu. Castro, Kruşçev'in Küba'yı yalnızlığa terk etmesinden dolayı öfkeliydi. ${ }^{126}$ Fakat sonradan sakinleşen Castro, barış1 korumak için yaptığı çabalardan dolayı Kruşçev'i tebrik ederek müzakerelere engel olabilecek olaylardan kaçınacağını belirtti. ${ }^{127}$

Moskova Radyosu'nun yayını Türkiye'de de yankı buldu. Türkiye, gizli anlaşmaların olabileceğine dair şüphe duymaya başlamıştı. Daha önce de ABD'nin birkaç kez Jüpiter füzelerinin sökülmesiyle alakalı Türkiye’ye tavsiyeler vermesi ve 27 Ekim'de Kruşçev'in Jüpiterlerin sökülmesini isteyip 28 Ekim'de de Küba'daki füzelerin söküleceğini ilan etmesi böyle bir gizli anlaşma ihtimalini güçlendirmişti. ${ }^{128}$ Aynı gün Kruşçev, Kennedy'e mesajında dünya barışının korunması için $A B D$ 'nin üzerine düşen mesuliyeti gerçekleştirmek amacıyla attığı adıma teşekkür etti ve ABD'nin Küba'yı işgal etmeme sözü vermesi üzerine adadaki üslerin kaldırılması için talimat verdiğini, BM Temsilcilerinin de bunu doğrulaması için anlaşmaya varmaya hazır olduklarını belirtti. Kruşçev, U Thant'le; Kremlin, Washington ve Havana temsilcileri arasındaki mevcut müzakerelere bağlı olarak tehlikeli durumun ortadan kalkmasına yardımcı olmak için Dışişleri Bakanı Birinci Yardımcısı V.V. Kuznetsov'u New York'a gönderdiğini bildirdi. ${ }^{129}$ Bunun ardından Kennedy de Kruşçev'e gönderdiği mektupta U Thant'in gayretlerinin Washington ve Kremlin'in işini büyük ölçüde kolaylaştırdığını ve BM aracılığıyla gerekli tedbirlerin bir anda alınabileceği vurguland1.

Liderlerin mektup teatisi ardından toplanan ExComm son gelişmeler ışı̆̆ında hava keşif uçuşlarının yapılmaması kararını aldı. Ancak füzelerin dışında IL-28'lerin de saldırı silahları tanımının içine alınıp bunların SSCB tarafından geri çekilmesi gerektiği üzerinde duruldu. ${ }^{130}$ Toplantı sonrası Kruşçev, Kennedy'ye yeniden bir mektup göndererek 27 Ekim'deki

\footnotetext{
${ }^{126}$ Dobbs, a.g.e., s. 420.

127 "Letter from Fidel Castro to Khrushchev", 28 October 1962; https://digitalarchive. wilsoncenter.org/document/114504.pdf?v =45584ab0dfdce9395b29471\%20df701c9bc (Erişim Tarihi: 26.03.2021).

128 Ayşegül Sever, "Yeni Bulgular Işı̆̆ında 1962 Küba Krizi ve Türkiye", $A \ddot{U S B F}$ Dergisi, 52(1), 1997, 647-660, s. 658.

${ }^{129}$ FRUS, Kennedy-Khrushchev Exchanges, p. 183-187.

${ }^{130}$ FRUS, Cuban Missile Crisis and Aftermath, p. 284.
} 
Dobrynin- R. Kennedy görüşmesinden bahisle, Türkiye'deki Jüpiterlerin sökülmenin dört-beş ay daha süreceğini ve bunun gizlilikle Dobrynin ve R. Kennedy arasında sürdürülmesi konusuna olumlu yaklaştığını belirtti. ${ }^{131}$ 17.00 itibariyle de SSCB'nin isteği doğrultusunda Küba'da 24 farklı yerde faal halde bulunan füze sistemleri sökülmeye başland1. ${ }^{132}$ Kruşçev anılarında, Kennedy'nin İtalya ve Türkiye'deki füzeleri sökeceğine dair söz vermesinin sembolik olduğunu, bu füzelerin esasen eskimiş olmasından dolayı ABD'nin bunları daha modern olanlarla değiştireceğini bildiğini yazacaktı. ${ }^{133}$

Nükleer silahlar Küba Krizi’nde krizinin ana kaynağını oluşturmuştu. Krizde oynadıkları rol ise caydırıcılığın en hassas örneklerinden biriydi. Nükleer savaş ihtimali Washington'ı ve Kremlin'i uçurumun eşiğine sürüklemişti. ${ }^{134}$ Aslında ABD'nin Küba'daki SSCB nükleer füze üslerine verdiği öfkeli tepki, 1823'te dönemin Başkanı James Monroe'nun Avrupa Devletleri'ni Amerikan kıtasına girmekten caydırmak için geliştirdiği Monroe Doktrini'yle tutarlıydı. Rusk'ın 1962 Eylül'ünde Senato'da dile getirdiği gibi, Monroe doktrini ABD'nin milli güvenlik çıkarın temel bir bileşeni olarak kald1. ${ }^{135}$

\section{Küba Krizi Sonrası}

Krizin çözümü yönünde Moskova ve Washington'un anlaşmaya varmasının ardından 29 Ekim'deki ExComm toplantısında Kennedy, krizi tüm boyutlarıyla ele alacak bir koordinasyon komitesinin kurulmasina onay verdi. ${ }^{136}$ Aynı tarihte New York'a gelen Kuznetsov, U Thant'le görüşerek Küba'daki Sovyet füzelerinin sökülmeye başlandığı bildirdi. Sökülme tamamlandığında Sovyetlerin BM Güvenlik Konseyi'ne bunu bildirmesini ve bu bildirinin gerçek olup olmadığının anlaşılması için BM'nin görevlendireceği heyetin doğrulamasını teklif etti. İkili arasındaki

\footnotetext{
${ }^{131}$ FRUS, Kennedy-Khrushchev Exchanges, p. 189.

${ }^{132}$ Pehlivanoğlu, a.g.e., s. 146.

${ }^{133}$ Nikita Khrushchev, Khrushchev Remembers: The Last Testament, (Translator: Strobe Talbott), Little, Brown and Company, New York, 1974, p. 512.

${ }^{134}$ David Coleman ve Joseph Siracusa, Real-World Nuclear Deterrence: The Making Of International Strategy, Praeger, London, 2006, p. 70.

135 Jonathan Colman, "Toward World Support and The Ultimate Judgment of History”, Fournal of Cold War Studies, 2019, 21(2), 150-173, p. 161.

${ }^{136}$ FRUS, Cuban Missile Crisis and Aftermath, p. 291.
} 
görüşmenin ayrıntıları için Stevenson, McCloy ve BM Güvenlik Konseyi Temsilci Yardımcısı Charles Yost, U Thant'le bir araya geldi. ${ }^{137} \mathrm{U}$ Thant Sovyetlerin, karantinanın bir an önce kaldırılmasını talebini Amerikalı yetkililere iletti. McCloy, füzeler konusunda herhangi bir güvence gelmeden karantinanın kaldırılmayacağını vurguladı. ${ }^{138} \mathrm{Bu}$ sırada krizin sonlandırıldığını resmiyete dökme konusunda hevesli olan Sovyet Birliği, Dobrynin aracılığıyla Jüpiterlerin söküleceğinin de eklenmiş olduğu şartları içeren mektubu R. Kennedy'e verdi. Mektubu okuyan Robert Kennedy, Türkiye'deki Jüpiterlerin sökülmesinin 4-5 ay süreceğini ifade ederek mektubu geri verirken "mektubun lüzumlu olduğu düşünülüyorsa biz de sizin keyfinizi kaçıracak şekilde bir mektup yazarız" demişti. ${ }^{139}$ $A B D$ ve SSCB arasındaki görüşmeler, Moskova'nın IL-28'leri geri çekme konusundaki isteksiliğinden dolayı devam etti. Süreçte bir an önce sonuca varmak isteyen Kruşçev, 30 Ekim'de Kennedy'e gönderdiği mektupta, herhangi bir prosedürü beklemeden karantinanın kaldırılmasını istedi. ${ }^{140}$

$1 \mathrm{Kasım}$ 'daki ExComm toplantısında McNamara, SSCB'nin füzeleri sökme anlaşmasına uymadıklarını, IL-28 bombardıman uçaklarının geri çekilecek SSCB silahları içerisinde yer alması gerektiğini ifade etti. Kennedy ise SSCB'nin IL-28'lerin geri çekilip çekilmediği konusunda adada inceleme yapılmasında 1srarcıyd1: ${ }^{141}$ "IL-28'ler ABD ve Batı Yarmküredeki ülkeleri tehdit ediyordu ve Küba'dan çıkarlmalıydl."142 Gerçekte ise Kruşçev'in IL-28'ler konusunda direnmesinin sebebi Castro'nun Sovyetlere sorunlar çıarmasıydı. Kruşçev, bu konuda uzlaşmak için SSCB Birinci Başkan Yardımcısı Anastas Mikoyan'ı Havana'yı gönderdi ancak Castro Sovyet devlet adamını günlerce bekletti. Nihayetinde Mikoyan'ı kabul ettiğinde ABD'nin ada üzerindeki uçuşlarını ve sabotaj faaliyetlerini sonlandırmasını ve karantinayı en kısa sürede kaldırmasını istedi. ${ }^{143}$ Karantinanın halâ kaldırılmaması Kruşçev açısından da bir sorundu. 12 Kasım'da Kennedy'e

\footnotetext{
${ }^{137}$ Pehlivanoğlu, a.g.e., s. 146-147.

${ }^{138}$ FRUS, Cuban Missile Crisis and Aftermath, p. 301.

${ }^{139}$ Arthur Schelesinger Jr, Robert Kennedy and His Time, Mariner Books, New York, 1978.

${ }^{140}$ FRUS, Kennedy-Khrushchev Exchanges, p. 190.

${ }^{141}$ FRUS, Cuban Missile Crisis and Aftermath, p. 339-341.

${ }^{142}$ FRUS, Kennedy-Khrushchev Exchanges, p. 201.

${ }^{143}$ Stern, a.g.e., p. 206.
} 
gönderdiği mektupta ABD'nin üstüne düşen sorumluluğu yerine getirmediğini belirterek "sözde karantinanızı ve Küba'nın karasularıyla hava alanını ihlâl etmeyi sonlandırın" diyerek tepkisini ortaya koydu. Öte yandan Kruşçev, IL-28'lerin geri çekilmesi konusunda daha yapıcı bir tutum gösterdi ve uygun bir zamanda uçakların ve ilgili tüm ekipmanın Küba'dan geri çekileceğini açıkladı. ${ }^{144}$ Akşama doğru Sovyet Büyükelçiliği Bolşoy Balesi'nin resepsiyonunda bir araya gelen R. Kennedy ve Dobrynin'in gündeminde de IL-28'ler vard1. R. Kennedy, otuz gün içinde IL-28'lerin kaldırılması durumunda ABD'nin karantinayı sonlandıracağı mesajını açıklayacağını muhatabına iletti. ${ }^{145}$ Ancak Kruşçev, iki gün sonra Kennedy'e gönderdiği mektupta IL-28'lerin kaldırılması için otuz günün yeterli olmayacağını, sürecin yaklaşık üç ay alacağını bildirdi. Bu sürenin kısaltılması karantinanın kaldırılmasına bağlı olabilirdi. ${ }^{146}$ ExComm üyeleri 17 Kasım'da, Sovyetlerin yaklaşı bir ay içinde IL-28'leri geri çekilmesinin onaylaması durumunda Kennedy'nin 20 Kasım'da basına yapacağı açıklamada bu durumun da dikkate alınması gerektiğini önerdiler. Rusk, 18 Kasım'da Kuznetsov'la bir araya gelecek McCloy'e, Kennedy'nin basına açıklama yapmadan önce IL-28'lerin hakkında olumlu bir cevap alınmasını gerektiğini ifade etti. ${ }^{147}$ Ertesi gün konuyu Kuznetsov'a ileten McCloy, uçak sorununun çözülmemesi durumunda Kennedy'nin basına bombardıman uçaklardan söz edeceğini açıkladı. Kuznetsov, Sovyetlerin IL-28'leri geri çekmeyi planladıklarını ama bunun diğer sorunlarla beraber kesin çözüme kavuşması konusunda 1 srarcıydı. ${ }^{148}$ R.Kennedy, aynı düşünceleri 19 Kasım'da Sovyetler Birliği Basın Ateşesi Georgi Bolshakov'a iletti. Eğer sorun çözülmezse ABD alçak irtifa uçuşlarına yeniden başlayacaktı. ${ }^{149} \mathrm{Bu}$ sırada Kennedy, NATO liderlerine IL-28'lerin geri çekilmemesi durumunda ABD'nin bu uçakları hava saldırısıyla ortadan kaldırmak zorunda olacaklarını bildirdi. ${ }^{150}$

\footnotetext{
${ }^{144}$ FRUS, Kennedy-Khrushchev Exchanges, p. 204-207.

145 A.g.e., p. 209.

${ }^{146}$ A.g.e., p. 211.

${ }^{147}$ FRUS, Cuban Missile Crisis and Aftermath, p. 480.

${ }^{148}$ A.g.e., p. 482-486.

${ }^{149}$ Schelesinger Jr, a.g.e.

${ }^{150}$ Michael Beschloss, The Crisis Years: Kennedy and Khrushchevs, 1960-1963, Open Road Media, New York, 2016.
} 
20 Kasım'da Kruşçev, beş gün önce Dobrynin aracıllı̆ıyla iletilen fikirleri göz önünde tuttuğunu belirterek Küba düğümünü çözmede istekli olduğunu belirten bir mektubu Kennedy'e gönderdi. Küba Krizi’nin kalıntılarını ortadan kaldırmak isteyen Kruşçev, IL-28'lerin saldırı kategorisi içinde bulunmadığını ve bunların on iki yaşında olduğunu açıklayarak yine de ABD'nin IL-28'lerin geri çekilmesine verdiği önemi anladığını Kennedy'e açılkladı. IL-28'leri ve bunlarla bağlantılı bütün SSCB personelini geri çekmeye hazır olduğunu hatta bu sürecin olabildiğince erkene çekileceğini bildirdi. Kruşçev son olarak anlaşma çerçevesinde karantinanın hemen kaldırılmasını istiyordu. ${ }^{151}$ Kruşçev'in mektubunun değerlendirilmesinin ardından karantinanın kaldırılmasına karar verildi. ${ }^{152}$ Gün içerisinde Dobrynin, R. Kennedy'nin ofisine gelerek 37. yaş günü münasebetiyle R. Kennedy'e hediye vermek istediğini söyledi. Bu hediye Kruşçev'in IL-28'leri otuz gün içinde geri çekileceğine dair güvence veren bir mektuptu. ${ }^{153}$ Kennedy için artık tamamıyla Küba Krizi'ni ve kalıntılarını gündemden kaldırma zamanıydı. Başkan, 18.00'deki basın toplantısında Sovyetlerin IL-28'leri otuz gün içerisinde geri çekileceğini ve karantinanın sona ereceğini açıkladı. ${ }^{154}$ Ayrıca bombardıman uçaklar için yerinde inceleme ve doğrulamanın gerçekleşmemesi durumunda ABD'nin Küba'yı işgal etmeme üzerine verdiği sözün yerine getirilemeyeceğini açıkladı. Karayip’te huzur ve barış Castro'nun saldırgan düşüncelerini sonlandırmasına bağlı hale gelmiş görünüyordu. ${ }^{155}$

Küba Krizi'nin sona erdirilmesiyle insanlığın nükleer savaş tehlikesinden kurtarıldığını belirten Kruşçev, 19 Aralık'ta Kennedy'e mektup göndererek nükleer silah denemeleri ve silahsızlanmayla ilgili bir anlaşma yapılması önerisinde bulundu. 28 Aralık'ta Moskova'ya verilen cevapta Kennedy'nin de nükleer testler konusunda, Kruşçev'le aynı görüşü paylaştığı belirtildi. ${ }^{156}$ Washington ve Kremlin, BM tarafından yürütülen

\footnotetext{
${ }^{151}$ FRUS, Kennedy-Khrushchev Exchanges, p. 215-222.

${ }^{152}$ FRUS, Cuban Missile Crisis and Aftermath, p. 502.

${ }^{153}$ Schelesinger Jr, A.e.

154“Kennedy's Press Conference”, 20 November 1962, https://www.jfklibrary.org/assetview er/archives/JFKWHA/1962/JFKWHA-144/JFKWHA-144 (Erişim Tarihi: 27.03.2021).

${ }^{155}$ Stern, a.g.e., p. 210.

${ }^{156}$ FRUS, Kennedy-Khrushchev Exchanges, p. 236-238.
} 
Küba Krizi çalışmalarına 7 Ocak 1963'te sonlandırma kararı aldı. Stenvenson ve Kuznetsov tarafindan ABD ve SSCB liderleri arasında anlaşmaya varılmasından dolayı BM'de devam eden görüşmeleri sona erdirme kararı U Thant'e iletildi. ${ }^{157}$ Krizin çözümünün ardından silahsızlanma konusunun gündeme gelmesiyle beraber Kennedy ve Macmillan, 15 Nisan'da Washington ve Londra'daki Sovyet Büyükelçiliklerine müşterek bir mektup gönderdi. Mektupta Şubat-Mart 1962 Cenevre Silahsızlanma Konferans1, nükleer test yasakları için metin üzerinde anlaşmaya varılma girişimi ve yine Ekim 1962'de de bu konuyla alakalı bir çabanın ilerleme sağlamamasından bahisle nihai bir karara ihtiyaç olduğu belirtildi. ABD ve İngiltere bu konularda kesin bir sonuca varılması yönünde niyet beyanında bulundu. ${ }^{158}$ $\mathrm{Bu}$ ortak mektuba olumlu yaklaşan Kruşçev, İngiltere ve ABD'nin üst düzey temsilcilerini kabul etmekten memnuniyet duyacağını ifade etti. ${ }^{159}$

Kremlin'de yumuşayan ortamın ardından Havana'da da krizin etkisi yok olmaya başladı. Amerikalı gazeteci Lisa Howard ile röportajında Castro, Washington'la ilişkilerin geliştirilebileceğini söyledi. Castro'nun bu niyeti Howard tarafından CIA'ye bildirildi. ${ }^{160}$ Castro'ya karşı planlanan CIA operasyonlarının Howard tarafından sızdırılmasından endişe duyan McCone, Howard'ın raporunun en hassas ve sınırlı dağıtıma tabi tutulmasını istedi. 10 Mayıs'ta röportajın yayınlanmasından Castro'nun yakınlaşma konusunda samimi olduğu ve barış için adımlar atması üzerine Washington'da uzlaşma için kapıyı açık bıraktı. ${ }^{161}$

10 Haziran'a gelindiğinde Amerikan Üniversitesi'nde konuşma yapan Kennedy, sorunların çözülmesinin ilk aşamasının sulh olduğuna değinerek düşmanlığın sonsuza kadar sürmeyeceğini açıkladı. Ayrıca $A B D$ ve SSCB'nin hem en güçlü hem de yıkım tehlikesine en yakın ülkeler olduğunu ifade ederek "İki ülke ve müttefikleri adaletli ve gerçek bir sulhtan

\footnotetext{
${ }^{157}$ Pehlivanoğlu, a.g.e., s. 165.

${ }^{158}$ FRUS, Kennedy-Khrushchev Exchanges, p. 268-270.

${ }^{159}$ A.g.e., p. 285-286.

${ }^{160}$ Sheldon Stern, a.g.e., p. 168.

161 David Talbot, Brothers: The Hidden History Of The Kennedy Years, Free Press, Washington, 2007.
} 
yanaydı ve silahlanma yarışının sona erdirilmesi konusuna kesin bir ilgi duyuyorlardı." diyerek sözlerini sonlandırdı. ${ }^{162}$

ABD ve SSCB, 20 Haziran'da gelecekte meydana gelebilecek çatışmaların önüne geçilebilmesi için Beyaz Saray ve Kremlin arasında, kırmızı hat olarak bilinen, doğrudan telefon hattı kurulması konusunda anlaşt1. 2 Temmuz'da Berlin'de konuşma yapan Kruşçev; uzayda, su altında ve atmosferde nükleer testlerin durdurulması konusunda anlaşma yapmak için hazır olduğunu ifade etti. ${ }^{163}$ Yeraltı hariç tüm nükleer denemelerin yasaklanmasına ilişkin Sınırlı Test Yasağı Anlaşması, 25 Temmuz'da parafe edilerek Moskova tarafından 5 Ağustos'ta imzaland1. ${ }^{164} \mathrm{Bu}$ anlaşma 24 Eylül'de ABD Senatosu tarafindan onayland,, 7 Ekim'de Kennedy tarafından imzalandı ve 10 Ekim'de yürürlüğe girdi. ${ }^{165}$

20 Eylül'de Büyükelçi Stevenson ile bir araya gelen Kennedy, Gine Büyükelçisi William Attwood aracılığıyla Küba'nın BM Büyükelçisi Carlos Lechuga'yla doğrudan gizli bir bağlantı kurması için onay verdi. Attwood ve Lechuga üç gün sonra bir araya geldiklerinde Lechuga, Kennedy'nin Amerikan Üniversitesi'ndeki konuşmasının Castro'da büyük umutlar doğurduğunu söyledi. Attwood'un Havana'ya gelmesini teklif etti. ${ }^{166}$ İkili arasındaki konuşmaları değerlendirmek için Attwood ve Robert Kennedy bir araya geldi. Robert Kennedy, Attwood'un Küba'yı ziyareti sırasinda kendisine herhangi bir zarar gelebilme ihtimalinden bahsetti. Bunun üzerine $B M$ 'de görüşmenin daha sağlıklı olacağının düşünen Attwood, 27 Eylül'de Lechuga'yla BM Delegeler Salonu'nda bir araya gelerek Castro'yla Küba harici bir yerde görüşebileceğini belirtti. 28 Ekim'de Lechuga, bu teklife Havana'nın olumsuz yanıt verdiğini açıkladı. Ancak Attwood, mesajın Castro'ya ulaştırıldığından emin değildi. ${ }^{167}$ Küba'yla

162 “Kennedy's Speech”, 10 June 1963, https://www.americanrhetoric.com/speeches/ jfkamericanuniversityaddress.html (Erişim Tarihi: 27.03.2021).

${ }^{163}$ FRUS, Soviet Union, Volume V, 1961-1963, p. 712.

${ }^{164}$ A.g.e., p. 715.

${ }^{165}$ Andreas Wenger ve Marcel Gerber, John F. Kennedy and Limited Test Ban Treaty: A Case Study Of Presidential Leadership, Presidential Studies Quartely, 2004, 29(2), 460487, p. 479.

${ }^{166}$ A.e.

${ }^{167}$ James Douglass, $\mathscr{F} F K$ and The Unspeakable: Why He Died $\mathcal{E}$ Why It Matters, Orbis Books, New York, 2008, p. 102. 
bir bağlantı kurmak isteyen Kennedy, 24 Ekim'de Fransız gazeteci Jean Daniel'den röportajın ardından Küba'ya gittiğinde, Castro'nun hatasından dolayı 1962 Ekiminde dünyayı nükleer savaşın eşiğine getirdiğinin farkında olup olmadığını sormasını istedi. 19 Kasım'da Havana Oteli'nde altı saat boyunca Castro'yla bir araya gelen Daniel, Kennedy'le yaptığ diyaloğu aktardı. Castro; o dönem itibariyle Küba'nın ABD tarafından işgal edileceğini düşündüğünü, bundan dolayı işgalden korktuğunu ve bunu caydırmak için böyle bir teşebbüse giriştiğini söyledi. Ardından Kennedy için iyimser sözler sarf etti ve yeniden ABD Başkanı seçilmesini istediğini belirtti. ${ }^{168}$ Ancak ABD-Küba arasındaki temasın ilerleyeceğ konusunda hevesli olan Castro'nun ümidi, 22 Kasım'da Kennedy'nin suikastıyla sona erecekti. ${ }^{169}$

Kruşçev anılarında Kennedy'den bahisle, ABD ve SSCB arasında gerginlik olsa da Kennedy'nin söylediklerine her zaman güvenilebileceğini yazdı. ABD'nin veya müttefiklerinin Küba'yı istila etmeme sözü vermesini sorgulamadan Kennedy'e güvenerek Küba'daki silahları derhal kaldırmıştı etti. Kruşçev, "Her ne kadar zit kutuplarda olsak dahi Kennedy ve ben askerî bir çatışmanın önüne geçme konusunda ortak bir dili daima bulabildik" diyerek felaketin eşiğinden nasıl dönüldügüunü kendi perspektifinden açıkladı. ${ }^{170}$

Krizi ilgilendiren ve pazarlıktan habersiz olan Türkiye ise sonuna kadar Kennedy'i destekledi. Jüpiterlerin Türkiye'nin kendi isteğiyle kaldırılmasını isteyen Kennedy, McNamara aracılığıyla Jüpiterler füzelerinin sökülüp ve yerine Polaris sınıfı denizaltıların konuşlandırılması önerisinde bulunmasını istedi. Milli Savunma Bakanı İlhami Sancar, Jüpiterlerin sökülmesinin Türkiye'nin maneviyatına zarar vereceğini ve NATO'ya duyulan itimadın sarsılacağ Dışişleri Bakanı Feridun Cemal Erkin ise Türkiye'nin güvenliğine ABD tarafından önem verildiğinin gösterilmesi için alternatif sağlanması gerektiği ve böylece Jüpiterlerin sökülmesinde herhangi bir güçlük olmayacağ düşüncesindeydi. ${ }^{172} \mathrm{Bu}$ tepkiler ışığında Türkiye'nin yumuşacığını düşünen

\footnotetext{
${ }^{168}$ A.g.e., p. 166.

${ }^{169}$ Stern, a.g.e., p. 211.

${ }^{170}$ Khrushchev, a.g.e., p. 514.

${ }^{171}$ FRUS, Eastern Europe; Cyprus; Greece; Turkey, p. 740.

${ }^{172}$ A.g.e., p. 741.
} 
ABD, Türkiye'ye F-104G savaş uçakları vererek Türkiye'yi konvansiyonel silahlarla destekleme kararı verdi. ${ }^{173}$

Jüpiterlerin Polaris denizaltılarıyla değiştirilmesi için iknalara devam eden McNamara, 5 Ocak 1963'te Sancar'a gönderdiği mesajda, teknolojinin hızla ilerlemesinin Jüpiterlerin füze gücü açısından ittifaka etkisinin kalmadığını, füzelerin düşman hava savunma sistemlerince kolayca tespit edilebildiğini, füzelerin konvansiyonel ve nükleer silahlara karşı savunmasız olduklarını belirtti. Sovyetler Birliği üzerinden de bir endişe yaratmaya çalışan McNamara, bu füzelerin SSCB'nin sürpriz bir saldırısından kurtulma ihtimalinin az olduğunu vurguladı. Bunların yaşanmaması için iki ülkenin ihtiyacı doğrultusunda Jüpiterleri daha iyi bir silah sistemiyle değiştirmek ve F-104G'lerin teslimatını hızlandırmak istediklerini belirtti. Ayrıca alternatif olarak önerilen Polaris denizaltılarının Akdeniz'de faaliyet göstermesini Polarislerin 1 Nisan'a kadar konuşlandırabileceğini açıkladı. ${ }^{174}$

Anlaşmaya varılmasının ardından Bakan Sancar, 23 Ocak'ta Meclis'te yaptığı konuşmada Jüpiterlerin yerine Polarislerin ikame edileceği konusunda ABD'yle olumlu görüşmeler yaptıklarını açıkladı. ${ }^{175} 1$ Nisan'da Jüpiterlerin sökülme işlemlerine başlandı. Ayrıca 14-15 Nisan'da Polaris sınıfı USS Sam Houston denizaltısı, İzmir'e bir liman ziyareti gerçekleştird. $\mathrm{Bu}$ ziyaret Türkiye'de ABD'nin Türkiye'nin güvenliğine olan bağlılığının bir işareti olarak kabul edildi. ${ }^{176}$ Jüpiterlerin sökülmesi, iki ülke arasında 1964 Johnson Mektubu'na kadar herhangi bir sorun teşkil etmedi. Mektupla beraber Ankara'daki Sovyet Büyükelçiliği’nden çıkan haberlerde Kennedy'nin Küba Krizi sırasında Türklere haber vermeden Jüpiterler üzerinden pazarlık yapmayı kabul ettiği açığa çıktı. ${ }^{177}$ Yaşananlardan sonra ABD’nin Jüpiter meselesinde tek taraflı olarak kararalması ve bunu Türklere dolaylı

\footnotetext{
${ }^{173}$ Sever, a.g.e., s. 659.

${ }^{174}$ FRUS, Eastern Europe; Cyprus; Greece; Turkey, p. 743-744.

175 Millet Meclisi Tutanak Dergisi, Dönem: 1, C. 11, Toplantı: 2, Birleşim: 34, 23.01.1963, s. 228.

${ }^{176}$ Sinan Ülgen ve George Perkovich, Turkey's Nuclear Future, Carnegie Endowment for International Peace, Washington, 2015, p. 68.

${ }_{177}$ Nur Criss, Strategic Nuclear Missiles In Turkey: The Jupiter Affair, 1959-1963, The Fournal of Strategic Studies, 1997, 20(3), 97-122, p. 119.
} 
olarak kabul ettirmesi, Türkiye'nin edilgen bir konuma nasıl sokulacağının önemli bir örneği olarak değerlendirilmeye başlandı. ${ }^{178}$

Rusk, Mart 1987'de Hawk's Cay, Florida'da krizde bulunan eski katılımcıların bir konferans düzenlemesine yardımcı olan James G. Blight'a bir mektup yazarak şunları kaleme aldı:

“Kennedy'nin Türkiye'deki Füpiterlerin Küba'daki füze alanlarmın kaldırlmasına engel olmasına izin vermeyeceği açıktı. Çünkü Füpiterler her halükârda çıkıyordu. O zamanlar Columbia Üniversitesi'nden Andrew Cordier'i aramamı ve ona $U$ Thant tarafindan Türkiye'deki Füpiterlerin ve Küba'daki füze alanlarını kaldırlmasını öneren bir açıklama yapmamı emretti. Bay Cordier, bu ifadeyi ancak bizden daha fazla sinyal aldiktan sonra $U$ Thant'in ellerine birakacaktı. Bu adım hiç atılmadı ve Bay Cordier'e verdiğim ifade hiç gün yüzüne çıkmadı. Bildiğim kadarıyla, Basskan Kennedy, Andrew Cordier ve ben bu özel adımı bilenlerdik." 179

\section{Sonuç}

Soğuk Savaş döneminde iki süper güç arasındaki Küba Krizi, Kennedy'nin ve Kruşçev'in çatışmadan kaçınma konusunda gösterdikleri çabaların sonucu sona erdi. On üç gün süren kriz, iki lideri ihtiyatlı davranmaya itti. Kennedy, bu krizdeki diplomatik çözümü önceden öngörebilmesine rağmen hasım kuvveti karşısında güçlü durarak ondan daha fazla imtiyaz koparma yolunu seçmiş görünmektedir. ABD Başkanı henüz krizin üçüncü gününde Türkiye'deki füzelerin sökülmesinden sonra bu sorunun çözüme kavuşacağını ifade etmişti. Ama Kennedy, hasımı karşısında korkmuş ve güçsüz görünmemek için bu teklifi Moskova'ya sunmamıştı. Karantinanın onaylanmasıyla Kruşçev'i zor durumda bırakan Kennedy, teklifin karşı taraftan gelmesini bekledi. Kruşçev, bu aşamada önce Küba'daki Sovyet füzelerine karşılık Türkiye'deki ABD füzelerinin kaldırılması önerdi. Türkiye'deki füzeleri zaten daha önceden kaldırmayı düşünen Kennedy için bu bir firsat oldu. Yine de zamana ihtiyaç duyan Kennedy, özellikle mektup teatisi sürecini sürekli açık tutarak sürecin kontrollü bir şekilde izlenmesini sağlayabilmiştir. Kennedy, Küba’yı işgal

\footnotetext{
${ }^{178}$ Sever, a.g.e., s. 660.

${ }^{179}$ FRUS, Cuban Missile Crisis and Aftermath, p. 275.
} 
etmeme ve karantinayı sonlandırma teklifi karşısında Küba'daki tüm silah sistemlerinin kaldırılmasını istedi. Bu teklifi kabul eden Kruşçev, yeniden Türkiye'deki füzeleri öne sürerek ABD’nin kaldırmasını istedi. Kennedy, Jüpiterler yerine Polarisler denizaltılarını ikame etme planını da bu süreçte hayata geçirmeyi başarmışt1. Kruşçev'e göre Kennedy, hem Küba'ya saldırmama hem de Küba'daki mevcut rejimin değişikliği için adım atmama sözü verdi. Fakat Kennedy, kriz sürecinde dahi Küba'da rejim değişikliği için plan yapmaya devam ediyordu. Krizde Washington ve Moskova arasındaki doğrudan iletişim kanallarının açık tutulması liderler düzeyindeki diplomasinin önemini bir kez daha ortaya koyması bakımından önem arz etmiştir.

\section{Summary}

The Cuban crisis between the two superpowers during the Cold War ended as a result of Kennedy's and Khrushchev's efforts to avoid conflict. Thirteen days of crisis have pushed the two leaders to act cautiously. Although Kennedy could anticipate the diplomatic solution in this crisis, he seems to have chosen to steal more privileges from him by standing strong in the face of his adversary force. The US President said that this issue would be resolved after the dismantling of missiles in Turkey on the second day of the crisis. However, Kennedy did not offer this offer to Moscow, so as not to look scared and powerless in the face of his adversary. Kennedy, who had put Khrushchev in a difficult position with the approval of the quarantine, waited for the proposal to come from the opposite side. Khrushchev, at this stage, first proposed the removal of US missiles in Turkey in exchange for Soviet missiles in Cuba. For Kennedy, who had already considered removing missiles in Turkey, this was an opportunity. Still needing time, Kennedy was able to ensure a controlled monitoring of the process, especially by keeping the letter exchange process open at all times. Kennedy called for the removal of all weapons systems in Cuba in the face of a proposal not to invade Cuba and to end the quarantine. Khrushchev, who agreed to this proposal, arguing again, asked the US to remove the missiles in Turkey. Kennedy had also succeeded in implementing his plan to replace the Polaris class submarines in place of the Jupiters in the process. According to Khrushchev, Kennedy promised both not to attack Cuba and not to take 
steps to change the current regime in Cuba. However, Kennedy continued to plan for regime change in Cuba, even during the crisis. Keeping the direct channels of communication between Washington and Moscow open during the crisis was important in that it once again demonstrated the importance of diplomacy at the level of leaders.

\section{Çatışma Beyanı:}

Makalenin ile ilgili herhangi bir kurum, kuruluş, kişi ile çıkar çatışması bulunmamaktadir.

\section{Araştırmacıların Katkı Oranı Beyanı:}

Araştırmanin hazırlanmasında birinci yazarın katkı oranı \%40, ikinci yazarın katkı oranı \%60'tır.

\section{KAYNAKÇA \\ Arşiv Belgeleri \\ Central Intelligence Agency (CIA)}

CIA Documents on the Cuban Missile Crisis, https://www.cia.gov/library/center-forthe-study-of-intelligence/csi-publications/books-and-monographs/Cuban\%20Missile \%20Crisis1962.pdf

CIA Reading Room: Memorandum for the file, 17 October, 1962, https://www.cia.gov/ readingroom/docs/CIA-RDP80B01676R001900100014-8.pdf (Erişim Tarihi: 15.03.2021).

CIA Reading Room; Brief Discussion with the President, 17 October 1962, https://www.cia.gov/readingroom/docs/CIA-RDP80B01676R001900100012-0.pdf

(Erişim Tarihi: 15.03.2021).

CIA Reading Room; Joint Evaluation of Soviet Missile Threat in Cuba, October 18, 1962, CIA- RDP78T05449A000200030001-8 https://www.cia.gov/readingroom/docs/ CIA-RDP78T05449A000200030001-8.pdf (Erişim Tarihi: 17.03.2021).

CIA Reading Room; Report to the President by the Security Resources Panel of the ODM Science Advisory Committe, Deterrence\&Survival in the Nuclear Age, 7 November, 1957, https://www.cia.gov/readingroom/docs/CIA-RDP86B00269R000300020003-3.pdf (Erişim tarihi: 13.03.2021).

CIA Reading Room; Special National Intelligence Estimate, The Military Building in Cuba, 19 September 1962, https://www.cia.gov/readingroom/docs/CIA-RDP80B01676 R001800050003-7.pdf (Erişim Tarihi: 14.03.2021).

Foreign Relations of the United States (FRUS)

FRUS, Soviet Union, Vol. V, 1961-1963.

FRUS, Kennedy-Khrushchev Exchanges, Vol. VI, 1961-1963.

FRUS, Cuba: January 1961-September 1962, Vol. X 1961-1963.

FRUS, Cuban Missile Crisis and Aftermath Vol. XI, 1961-1963.

FRUS, Eastern Europe; Cyprus; Greece; Turkey, Vol. XVI, 1961-1963. 
1962 Küba Krizi: Amerikan Arşivleri Üzerinden Bir Okuma

\section{Kitaplar}

BESCHLOSS, Michael; The Crisis Years: Kennedy and Khrushchevs, 1960-1963, Open Road Media, New York, 2016.

COLEMAN, David \& SIRACUSA, Joseph; Real-World Nuclear Deterrence: The Making Of International Strategy, Praeger, London, 2006.

DALLEK, Robert; An Unfinished Life: Fohn F. Kennedy, 1917-1963, Little, Brown and Company, New York, 2003.

DOBBS, Michael; Geceyarısına Bir Kala: Nükleer Savaşın Beşiğinde Kennedy, Kruşçev ve Castro. (Çev. Erhun Yücesoy). YKY, İstanbul, 2010.

DOUGLASS, James; $\mathscr{F F K}$ and The Unspeakable: Why He Died $\mathcal{E}$ Why It Matters, Orbis Books, New York, 2008.

FREDERICK, Kempe, Berlin 1961: Kennedy, Khrushcher, and the Most Dangerous Place on Earth, G.P. Putnam's Sons, New York, 2011.

FREEDMAN, Lawrence; Kennedy's Wars: Berlin, Cuba, Laos And Vietnam, Oxford University Press, New York, 2000.

GADDIS, John Lewis; Strategies Of Containment: A Critical Appraisal Of American National Security Policy During The Cold War, Oxford University Press, New York, 2005.

GETCHELL, Michelle; The Cuban Missile Crisis And The Cold War: A Short History With Documents, Hackett Publising, Indianapolis, 2018.

HUNT, Michael; Crises in US Froeign Policy: An International History Reader, Yale University Press, London, 1996.

KENNEDY, Robert; Thirteen Days, Macmillan Publishers, London, 1968.

KHRUSHCHEV, Nikita; Khrushchev Remembers: The Last Testament, (Translator: Strobe Talbott), Little, Brown and Company, New York, 1974.

LÜTHI, Lorenz; Cold Wars: Asia, The Middle East, Europe, Cambridge University Press, New York, 2015.

MAY, Ernest \& ZELIKOW, Philip; Kennedy Tutanaklarn ve Türkiye Üzerine Gizli Pazarliklar, (Çev. Mehmet Harmanc1), Sabah, İstanbul, 1998.

PEHLIVANOĞLU, Öner; Küba Krizi ve Nükleer Savaş Eşiğinde Türkiye, Kastaş, İstanbul, 2003.

SCHELESINGER, Arthur Jr.; Robert Kennedy and His Time, Mariner Books, New York, 1978.

STERN, Sheldon; The Week The World Stood Still: Inside The Secret Cuban Missile Crisis, Stanford University Press, California, 2005.

TALBOT, David; Brothers: The Hidden History Of The Kennedy Years, Free Press, Washington, 2007.

ÜLGEN, Sinan \& PERKOVICH, George; Turkey's Nuclear Future, Carnegie Endowment for International Peace, Washington, 2015.

YAVUZ, Turan; Satılık Müttefik: Gizli Belgeler Işığında 1962 Küba Füze Krizi ve Türkiye, Destek Yayınları, İstanbul, 2019.

Makaleler

ALLYN, Bruce \& BLIGHT, James G. \& WELCH, David; "Essence Of Revision: Moscow, Havana and the Cuban Missile Crisis", International Security, 14(3), 1989/1990. AMADOR, FRANCISCO V., "The Rio de Janeiro Treaty: Genesis, Development, and Decline of a Regional System of Collective Security", University of Miami InterAmerican Law Review, Number 1, Vol 17, Fall 1985.

COLMAN, Jonathan; "Toward World Support and The Ultimate Judgment of History”, Fournal of Cold War Studies, 21(2), 2019.

CRISS, Nur B; "Strategic Nuclear Missiles in Turkey: The Jupiter Affair, 1959-1963", The Fournal of Strategic Studies, 20(3), 1997. 
GADDIS, John Lewis; "The Emerging Post-Revisionist Synthesis On The Origins The Cold War", Diplomatic History, 7(3), 1983.

GARCIA-AMADOR, Francisco V., "The Rio de Janeiro Treaty: Genesis, Development, and Decline of a Regional System of Collective Security", University of Miami Inter-American Law Review, number 1, vol 17, Fall 1985.

HARMER, Tanya; "The Cuban Question And The Cold War In Latin America: 19591964", Fournal of Cold War Studies, 21(3), 2019.

SEVER, Ayşegül; "Yeni Bulgular Işığında 1962 Küba Krizi ve Türkiye”, $A \ddot{U S B F}$ Dergisi, 52(1), 1997.

WENGER, Andreas \& GERBER, Marcel; "John F. Kennedy and Limited Test Ban Treaty: A Case Study Of Presidential Leadership”, Presidential Studies Quartely, 29(2), 2004.

\section{Süreli Yayınlar}

Akis Mecmuas1, 1962, Cilt: XXVI, Sayı: 435.

Millet Meclisi Tutanak Dergisi, Dönem: 1, C. 11, Toplantı: 2, Birleşim: 34, 23.01.1963. Internet Siteleri

Bromley K. Smith, Organizational History of the National Security Council during the Kennedy and Johnson Administrations, 1988, https://historyinpieces.com/documents/ files/2014/08/Smith-NSC-History-1988.pdf (Erişim tarihi: 20.03.2021).

http://www.oas.org/juridico/english/treaties/b-29.html (Erişim Tarihi: 20.03.2021). https://microsites.jfklibrary.org/cmc/oct18/doc2.html (Erişim Tarihi: 18.03.2021). https://microsites.jfklibrary.org/cmc/oct20/ (Erişim tarihi: 20.03.2021).

https://microsites.jfklibrary.org/cmc/oct22/doc5.html (Erişim Tarihi: 18.03.2021).

Kennedy's Press Conference, 20 November 1962, https://www.jfklibrary.org/assetviewer /archives/JFKWHA/1962/JFKWHA-144/JFKWHA-144 (Erişim Tarihi: 27.03.2021).

Kennedy's Speech, 10 June 1963, https://www.americanrhetoric.com/speeches/ jfkamericanuniversityaddress.html (Erişim Tarihi: 27.03.2021).

Letter from Fidel Castro to Khrushchev, 26 October 1962, https://microsites.jfklibrary. org/cmc/oct26/doc2.html (Erişim tarihi: 24.03.2021).

Letter from Fidel Castro to Khrushchev, October 28, 1962; https://digitalarchive. wilsoncenter.org/document/114503 (Erişim Tarihi: 24.03.2021).

Letter from Khrushchev to Fidel Castro, October 28, 1962; https://digitalarchive. wilsoncenter.org/document/114504.pdf?v $=45584 \mathrm{ab0dfdce} 9395 \mathrm{~b} 29471 \mathrm{df} 701 \mathrm{c} 9 \mathrm{bc}$

(Erişim Tarihi: 26.03.2021).

Meeting of Robert Kennedy and Dobrynin, 27 October 1962, https://microsites. jfklibrary.org/cmc/oct27/ (Erişim tarihi: 25.03.2021).

Radio and Television Report to the American People on the Soviet Arms Buildup in Cuba https://microsites.jfklibrary.org/cmc/oct22/doc5.html (Erişim tarihi: 20.03.2021).

The National Security Archives, October 14, 1962: U-2 phoghraph of a truck convoy approaching a deployment soviet MEBMs near Los Palacios at San Cristobal, https://nsarchive2.gwu.edu/nsa/cuba_mis_cri/14.jpg (Erişim tarihi: 31.03.2021).

The National Security Archives, October 14, 1962: U-2 phograph of MRBM site two nautical miles away from the Los Palacios deployment https://nsarchive2.gwu.edu/ nsa/cuba_mis_cri/15.jpg (Erişim tarihi: 31.03 .2021 ).

The National Security Archives, September 28, 1962: photograph of Soviet ship Kasimov with IL-28 fuselages in crates, https://nsarchive2.gwu.edu/nsa/cubamiscri /13.jpg (Erişim tarihi: 31.03.2021). 